\title{
WATER QUALITY OF THE KLANG RIVER, SELANGOR, MALAYSIA AND HEAVY METAL REMOVAL USING PHYTOREMEDIATION
}

\author{
HANAFIAH, M. M. ${ }^{12^{*}}-$ HASAN, R. M. ${ }^{1}-$ NIZAM, N. U. M. ${ }^{1}-$ AZIZ, N. H. A. ${ }^{1}$ \\ ${ }^{I}$ Department of Earth Sciences and Environment, Faculty of Science and Technology, Universiti \\ Kebangsaan Malaysia, 43600 Bangi, Selangor, Malaysia \\ ${ }^{2}$ Centre for Tropical Climate Change System, Institute of Climate Change, Universiti \\ Kebangsaan Malaysia, 43600 Bangi, Selangor, Malaysia \\ *Corresponding author \\ e-mail:mhmarlia@ukm.edu.my \\ (Received 23 $3^{\text {rd }}$ Mar 2021; accepted $12^{\text {th }}$ Aug 2021)
}

\begin{abstract}
In this study, nine physicochemical parameters including dissolved oxygen, biochemical oxygen demand, chemical oxygen demand, total suspended solids, ammoniacal nitrogen, conductivity, temperature, $\mathrm{pH}$ and heavy metal contents from five sampling stations were measured to determine the water quality index (WQI) of the Klang River, Selangor, Malaysia. The WQI of the first and second sampling stations were classified as classes II and III, respectively. Biological analysis of total coliform and fecal coliform bacteria shows that three sampling stations were highly polluted with $17,500,11,300$ and $10,700 \mathrm{CFU} / 100 \mathrm{~mL}$ of these bacteria. The efficiency of phytoremediation in removing heavy metals (i.e. As, $\mathrm{Cd}, \mathrm{Cu}, \mathrm{Mg}, \mathrm{Fe}, \mathrm{Pb}, \mathrm{Zn}$ and $\mathrm{Hg}$ ) was determined using Pistia stratiotes and Lemna minor $\mathrm{L}$. Phytoremediation using Pistia stratiotes was able to reduce the concentrations of $\mathrm{As}, \mathrm{Cd}, \mathrm{Cu}, \mathrm{Fe}, \mathrm{Pb}, \mathrm{Zn}$, $\mathrm{Mg}$ and $\mathrm{Hg}$ to $96.62 \%, 95.65 \%, 60.38 \%, 61.67 \%, 99.24 \%, 32.97 \%, 53.23 \%$ and $96.59 \%$, respectively. Lemna minor L. was able to remove approximately $10.97 \%, 83.33 \%, 35.75 \%, 39.97 \%, 100 \%, 15.32 \%$, $23.81 \%$ and $90.91 \%$ of $\mathrm{As}, \mathrm{Cd}, \mathrm{Cu}, \mathrm{Fe}, \mathrm{Pb}, \mathrm{Zn}, \mathrm{Mg}$ and $\mathrm{Hg}$, respectively. Both plants were able to reduce the heavy metal contents in river water samples at the end of the treatment day.
\end{abstract}

Keywords: water treatment, Pistia stratiotes, Lemna minor L., water pollution, aquatic plants

\section{Introduction}

Water pollution has had negative impacts on the environment and human health. The pollutants can come from point sources such as industrial and domestic wastes, while pollutants from non-point sources include agriculture activities and urban runoff (Banch et al., 2020; Harun et al., 2020). Rapid development has contributed to a high amount of human wastes, including local, industrial, commercial and transportation wastes which ends up in rivers (Khataee et al., 2012). In addition, the increase in human population density and the development of industries nearby rivers and coastal areas have increased the pollutant inputs and deteriorated the water quality of the surrounding area (Jindal and Sharma, 2011; Hanafiah et al., 2018a; Harun et al., 2020). Urban rivers have also become polluted due to the discharge from sewage treatment plants as well as overflowing sewage caused by rainfall, leading to fecal contamination which was a major concern in the river near the town area. Nonetheless, industrial and household wastes which were discharge directly or through leakages in the sewage systems flowed into water sources thus causing excessive pollution of surface and underground water (Manikam et al., 2019). Contaminated discharges and effluents from anthropogenic activities have resulted in severe degradation of river water quality (Kamarudin et al., 2019). A large number of rivers were polluted, to the extent that the rivers are not rehabilitate, and the access to a 
clean and safe water supply has become a challenge for the government to overcome (Ghazali and Hanafiah, 2016; Ashraf and Hanafiah, 2019; Aziz and Hanafiah, 2020). Accordingly, water pollution issue has received increasing attention globally in recent years (Lin et al., 2015).

Malaysia is no exception in facing an environmental issue related to water pollution (DOE, 2018; Hanafiah et al., 2018b). Klang River which is located in Klang Valley is a river flows through Kuala Lumpur and Selangor in Malaysia and eventually flows into the Straits of Malacca. It is approximately $120 \mathrm{~km}(75 \mathrm{mi})$ in length and drains a basin of about $1,288 \mathrm{~km}^{2}$ (497 sq. mi). Rapid development has lessened certain stretches of the river to the point that it resembles a large storm drain in some places (Banch et al., 2020) contributing to flash floods in Kuala Lumpur, especially after heavy rain. The two most important tributaries are Selangor River and Langat River. There were two major dams at the upstream of Klang Valley namely Batu Dam and Klang Gates Dam, however, these dams have been polluted due to the untreated sewage and industrial wastes. Sewage goes straight into the river due to inadequate water piping not being linked to the sewage concentration pipes. The vast industrialization, urbanization and rapid economic development in Kuala Lumpur have increased the levels of pollution in the rivers, especially Klang River suffers the most since it flows through the state of Selangor and Kuala Lumpur. The pollution mainly caused from the development which raises numerous environmental concerns along the Klang River. Meanwhile, human activities have caused a substantial hydrological deformation (Safauldeen et al., 2019). The hasty urbanization has directed to both the increasing request for water consumption and the increasing levels of river water pollution in Malaysia (Banch et al., 2019a; Al-Raad et al., 2020).

Nevertheless, water treatment is also crucial to improve water quality, so that the water can be more acceptable to be consumed for various purposes (Sun et al., 2012). Among a number of water treatment methods that have been developed, phytoremediation is one of the alternative technologies that can be implemented to reduce contaminants in river water (Hanafiah et al., 2020). Phytoremediation is a nature-based treatment which uses plants as a phytoremediation agent and it has potential benefits in restoring a balance in stressed environment (Aziz et al., 2020). It is an emerging low-cost technology, non-intrusive and aesthetically pleasing using the remarkable ability of green plants to metabolize various elements and compounds from the environment in their tissues (Selamat et al., 2014). Phytoremediation technology is applicable to a broad range of contaminants, including metals and radionuclides, as well as organic compounds like chlorinated solvents, polycyclic aromatic hydrocarbons, pesticides, explosives and surfactants ( $\mathrm{Ng}$ and Chan, 2016). The objectives of this study were to determine the water quality of Klang River based on the physical, chemical and biological characteristics and to determine the removal rate of contaminants using Pistia stratiotes (water lettuce) and Lemna minor L. (duckweed) as phytoremediation agents. Pistia stratiotes and Lemna minor L. are invasive floating aquatic macrophytes which have the ability in a remediation of diverse chemical pollutants (Jayasri and Suthindhiran, 2017; Schwantes et al., 2019).

\section{Materials and Methods}

\section{Sampling and Laboratory Analysis}

The first sampling station (ST1) was at Jalan Jelatek, near the fire and rescue station. Second sampling station (ST2) was conducted at Jalan Datuk Keramat, near the railway station and car wash shops. The third sampling station (ST3) was at Jalan Gurney, near 
the restaurants complexes. Fourth sampling station (ST4) was at Jalan Sungai Baru which located near the residential complexes and the fifth sampling station (ST5) was at Jalan Dang Wangi which located near the markets and shops. The coordinates of five sampling stations are provided in Table 1. The samplings were conducted two times with a total of three samples were taken at site for replication to get a more accurate and precise results, with a volume of $100 \mathrm{ml}$ per sample. Six parameters were taken to determine the water quality index for Klang River which were dissolved oxygen (DO), biochemical oxygen demand (BOD), chemical oxygen demand (COD), total suspended solid (TSS), ammoniacal nitrogen $\left(\mathrm{NH}_{3}-\mathrm{N}\right)$ and $\mathrm{pH}$. Other parameters like conductivity, temperature, heavy metals and coliform bacteria have also been taken into account.

Table 1. The coordinates of the five sampling stations

\begin{tabular}{c|c}
\hline Stations & Coordinate \\
\hline ST1 & $3^{\circ} 9^{\prime} 52.3872^{\prime \prime} \mathrm{N} 101^{\circ} 44^{\prime} 4.1496 " \mathrm{E}$ \\
ST2 & $3^{\circ} 9^{\prime} 50.7816^{\prime \prime} \mathrm{N} 101^{\circ} 43^{\prime} 27.9804^{\prime \prime} \mathrm{E}$ \\
ST3 & $3^{\circ} 9^{\prime} 57.2832^{\prime \prime} \mathrm{N} 101^{\circ} 43^{\prime} 1.5744 " \mathrm{E}$ \\
ST4 & $3^{\circ} 9^{\prime} 44.6832^{\prime \prime} \mathrm{N} 101^{\circ} 42^{\prime} 38.7468^{\prime \prime} \mathrm{E}$ \\
ST5 & $3^{\circ} 9^{\prime} 15.0948^{\prime \prime} \mathrm{N} 101^{\circ} 42^{\prime} 2.6244 " \mathrm{E}$ \\
\hline
\end{tabular}

In order to monitor and assess the water quality of river system, Water Quality Index (WQI) has been widely applied which involves the classification of rivers or river segments into classes of quality in a descending order (Asman et al., 2017; Ashraf and Hanafiah, 2017; Harun and Hanafiah, 2018). The index is a numeric expression used to transform a large collection of water quality data into a single index number, which represents the water quality level. A river with high WQI value reflects that the water body is in good condition and vice versa (Suratman et al., 2015). WQI consisted of six parameters, namely DO, BOD, COD, SS, $\mathrm{NH}_{3}-\mathrm{N}$ and $\mathrm{pH}$. The WQI of Klang River was determined using in the Eq. 1:

$$
\begin{aligned}
\mathrm{WQI}= & (0.22 \times \mathrm{SIDO})+(0.19 \times \mathrm{SIBOD})+(0.16 \times \mathrm{SICOD})+ \\
& (0.15 \times \mathrm{SIAN})+(0.16 \times \mathrm{SISS})+(0.12 \times \mathrm{SIpH})
\end{aligned}
$$

where,

SIDO = Sub-index for DO; SIBOD = Sub-index for BOD; SICOD = Sub-index for COD; SIAN = Sub-index for AN; SISS $=$ Sub-index for SS; and SIpH $=$ Sub-index for $\mathrm{pH}$.

The reading of DO was taken on the first day and then the samples were kept in a $20^{\circ} \mathrm{C}$ incubator for five days. After five days, the DO reading was taken again. The calculation of $\operatorname{BOD}(E q .2)$ and TSS (Eq. 3) are as follows:

$$
\begin{gathered}
\mathrm{BOD}=\mathrm{DO} \text { (reading on the first day) }-\mathrm{DO} \text { (reading on the fifth day) } \\
\text { Total suspended solids }(\mathrm{mg} / \mathrm{L})=\frac{A-B}{V} \times 1000 \mathrm{~mL}
\end{gathered}
$$

where,

A = Weight of filter paper after filtration (weight of filter paper + dried residue), $\mathrm{mg}$; $\mathrm{B}$ $=$ Weight of filter paper before filtration (weight of filter paper), $\mathrm{mg} ; \mathrm{V}=$ Volume of filtered water sample, $\mathrm{mL}$. 


\section{Phytoremediation}

The collected Pistia stratiotes and Lemna minor L. were put on a filter paper to remove excess water and were then transferred into a $5 \mathrm{~L}$ plastic containing water sample from different sampling stations. Before the plants were transferred, the water characteristics were determined by analyzing the heavy metals content such as $\mathrm{Pb}, \mathrm{Zn}, \mathrm{Mg}, \mathrm{As}, \mathrm{Cd}, \mathrm{Fe}$, $\mathrm{Al}$ and $\mathrm{Li}$ (Ugya, 2015). After 7, 14 and 21 days, the water was analyzed to get the value of its characteristics. Figure $1 a$ and $1 b$ show the growth of Pistia stratiotes and Lemna minor L. in the laboratory. The parameters before phytoremediation was noted as initial value, while the value after phytoremediation was indicated as final value. All the analysis was done using the methodology according to APHA (1995) and APHA (1998).

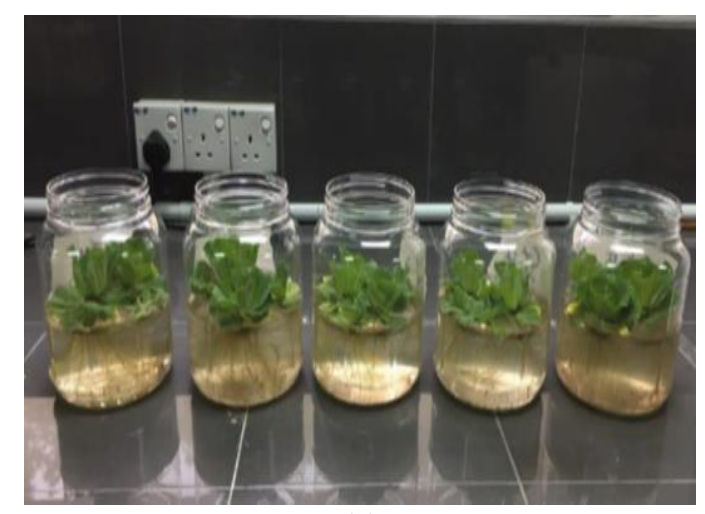

(a)

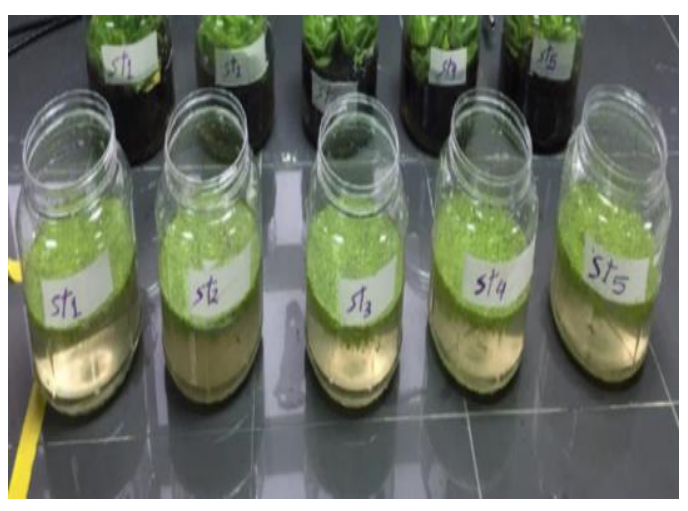

(b)

Figure 1. The growth of a) Pistia stratiotes and b) Lemna minor L. in the laboratory

\section{Statistical Analysis}

Statistical analysis was performed using the statistical packages of IBM SPSS software (version 22, New York, US, 2020). Statistical significant difference analysis was carried out by using one-way ANOVA test to show the $\mathrm{P}$ values of each parameter between the five sampling stations.

\section{Results and Discussion}

\section{Water Quality Index}

Nine parameters namely DO, BOD, COD, TSS, $\mathrm{NH}_{3}-\mathrm{N}$, conductivity, temperature, $\mathrm{pH}$ and heavy metals were measured to determine the water quality of Klang River. All parameters for five sampling stations were compared with the water quality index (WQI) of the Department of Environment (DOE).

All samples were collected at two times sampling where the first sampling was conducted during the rainy season and the second sampling was conducted during the dry season. Overall, the average value of WQI for ST1, ST2, ST3, ST4 and ST5 were 74\% (class III), 75\% (class III), 76\% (class III), 81\% (class II) and 73\% (class III), respectively. Table 2 shows the average value of WQI at five sampling stations.

Most stations were classified in class III of WQI except for ST4 which is in a class II. According to the classification of the river water in WQI, class III indicated that water was slightly polluted with extensive treatment required such as coagulation process, 
flocculation, sedimentation, filtration and disinfection. Class II (ST4) considered as slightly polluted and a conventional treatment was required. The main sources of pollution at the sampling site was due to various land use activities such as malls, condominium residential, commercial activities, industrial factories, municipal sewers, wet market, sand mining and landfill which affected the water quality of Klang River. Figure 2 shows the average value of all parameters for five sampling stations at two sampling times.

Table 2. The average value of WQI for five sampling stations

\begin{tabular}{c|c|c|c|c|c|c|c|c}
\hline Station & $\begin{array}{c}\text { DO } \\
(\mathbf{m g} / \mathbf{L})\end{array}$ & $\begin{array}{c}\mathbf{B O D} \\
(\mathbf{m g} / \mathbf{L})\end{array}$ & $\begin{array}{c}\mathbf{C O D} \\
(\mathbf{m g} / \mathbf{L})\end{array}$ & $\begin{array}{c}\mathbf{N H} 3-\mathbf{N} \\
(\mathbf{m g} / \mathbf{L})\end{array}$ & $\begin{array}{c}\text { TSS } \\
(\mathbf{g} / \mathbf{L})\end{array}$ & $\mathbf{p H}$ & $\begin{array}{c}\text { Temp. } \\
\left({ }^{\circ} \mathbf{C}\right)\end{array}$ & $\begin{array}{c}\text { Conductivity } \\
(\boldsymbol{\mu s} / \mathbf{c m})\end{array}$ \\
\hline ST1 & 8.305 & 5.015 & 49 & 1.62 & 0.005 & 6.6 & 23.755 & 183.4 \\
ST2 & 10.86 & 5.625 & 7.75 & 2.475 & 0.018 & 6.6 & 24.21 & 187.35 \\
ST3 & 7.645 & 4.52 & 16 & 2.195 & 0.006 & 6.5 & 23.735 & 181.2 \\
ST4 & 7.12 & 4.595 & 22.15 & 1.215 & 0.010 & 6.545 & 23.46 & 179.75 \\
ST5 & 7.53 & 4.92 & 57 & 1.095 & 0.015 & 6.6 & 24.195 & 218.75 \\
\hline
\end{tabular}
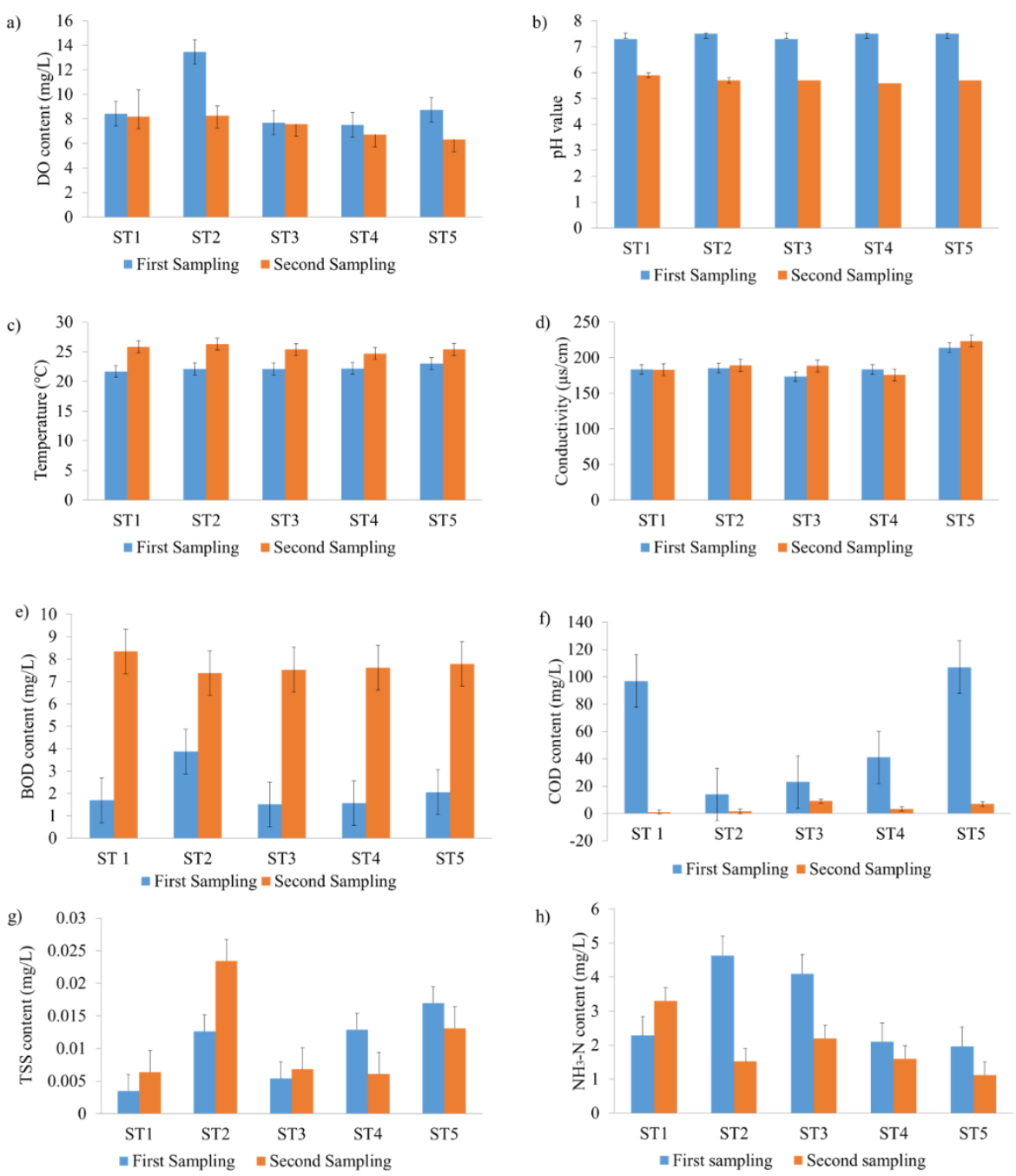

Figure 2. Average value of a) $D O, b) \mathrm{pH}$, c) temperature, d) conductivity, e) BOD, f) $C O D, g$ ) TSS and h) $\mathrm{NH}_{3}-\mathrm{N}$ for five sampling stations at two sampling times 
The average of DO value at all five stations were ranged between $7.12 \mathrm{mg} / \mathrm{L}$ to $10.86 \mathrm{mg} / \mathrm{L}$. ST2 has the highest average of DO value among the five sampling stations, which was about $10.86 \mathrm{mg} / \mathrm{L}$. While the average DO at ST4 was the lowest with a value of $6.12 \mathrm{mg} / \mathrm{L}$. Most stations were classified in class I ( $7 \mathrm{mg} / \mathrm{L})$, except for ST4 and ST5 (during the first sampling) which were in class II. All average values were statistically analyzed using one-way ANOVA test and there was no significant difference of DO between two sampling times for all stations with $p$-value $=0.369(>0.05)$ and with a total standard deviation (SD) of 1.8233. According to Ismail and Salim (2013), DO content was affected by the presence of organic and inorganic materials in the water.

At the first sampling the $\mathrm{pH}$ for ST1 was 7.3, while at the second sampling, the $\mathrm{pH}$ was 5.9. For ST2, the $\mathrm{pH}$ values at the first and second samplings were $\mathrm{pH} 7.5$ and 5.7, respectively. The $\mathrm{pH}$ value for ST3 was 7.3 at first sampling and was 5.7 at second sampling. ST4 has a $\mathrm{pH}$ value of 7.5 at first sampling and showed a minimum $\mathrm{pH}$ at second sampling with a value of 5.59. The $\mathrm{pH}$ value at ST5 was 7.5 at first sampling and 5.7 at second sampling. All sampling stations during the second sampling was acidic with a $\mathrm{pH}$ value of below 6 and based on the WQI, the $\mathrm{pH}$ of the five sampling stations in second sampling were classified in class III, which was between 5 and 6 . At the first sampling, all five stations have a $\mathrm{pH}$ of more than 7 , which was alkaline and were classified in class I. Based on the statistical analysis using ANOVA, it was indicated that there was high significant difference in $\mathrm{pH}$ between the five sampling stations on the first and second sampling times. All stations in the first sampling were recoded alkaline, meanwhile in second sampling showed an acidic $\mathrm{pH}$ of water with $p$-value $p<0.05$ and the total SD was 0.91 . The acidity of $\mathrm{pH}$ during second sampling might be due to the solidifiers and hardens of organic materials from non-seasonal human activities such as restaurants and cafeterias nearby which produced food wastes, plant residues and animal residues.

For ST1, the minimum temperature value was between $21.7^{\circ} \mathrm{C}$ for first sampling and for second sampling was $25.81{ }^{\circ} \mathrm{C}$. In the ST2, the average temperature was between $22.1^{\circ} \mathrm{C}$ for first sampling and $26.31{ }^{\circ} \mathrm{C}$ for second sampling. For ST3, the average temperature was between $22.1{ }^{\circ} \mathrm{C}$ at first sampling and $25.37{ }^{\circ} \mathrm{C}$ for second sampling. Average value for ST4 was between $22.2^{\circ} \mathrm{C}$ for first sampling and $24.72{ }^{\circ} \mathrm{C}$ for second sampling. ST5 was ranged between $23{ }^{\circ} \mathrm{C}$ for first sampling and $25.39{ }^{\circ} \mathrm{C}$ for second sampling. Based on one-way ANOVA analysis, there was higher significant difference in temperature between the two samplings and within stations. The $p$-value of all samples $p<0.05$ of temperature with the total SD of 1.81 .

The average value range for conductivity was between $179.75 \mu \mathrm{s} / \mathrm{cm}$ and $218.75 \mu \mathrm{s} / \mathrm{cm}$. The conductivity for most of the sampling stations were slightly higher during the second sampling as compared to the value of the first sampling. According to the WQI, it can be deduced that the conductivity of all five sampling stations in both sampling times were classified in class I $(<1000)$. Based on the one-way ANOVA test that has been conducted, there was no significant difference in the conductivity between sampling stations and between the two times sampling, with $p=0.62(>0.05)$ and a SD of 16.87. The higher conductivity values during the second sampling in the dry season was due to the fact that the water carried all the elements that help to increase the conductivity such as iron and cadmium, which were considered as high conductivity of the same elements.

The average BOD for the two times sampling were between $4.52 \mathrm{mg} / \mathrm{L}$ (ST3) to $5.62 \mathrm{mg} / \mathrm{L}$ (ST2). The BOD values for all sampling stations at two sampling times were 
classified as class III according to WQI. From the statistical analysis using one-way ANOVA test that has been performed, it can be interpreted that there was high significant difference between two sampling times with $p$-value $<0.05$, while there was a significant difference between sampling stations with $p$-value $=0.01$ and a total SD of 4.08. During dry session at second sampling, the BOD value was higher due to the decayed plants and animal's wastes especially at ST5 and also because of the presence of anthropogenic effluents including faeces, urine, detergents, fats, oil and grease (Banch et al., 2019b). Faeces contain organic and biological contamination and if it drains into water without being treated first, it can increase the risk of water diseases (Wahab et al., 2019). Rainy season during the first sampling resulted in lower BOD value because of a good oxidation in water as well as due to an increased volume and flow rate of the river.

The average value of COD recorded at all sampling stations for two sampling times were between $7.75 \mathrm{mg} / \mathrm{L}$ which was at ST2, to $57 \mathrm{mg} / \mathrm{L}$ at ST5. According to WQI classification, ST2 was classified in class I $(<10 \mathrm{mg} / \mathrm{L})$, while ST3 and ST4 were in class II (10-25 mg/L). ST1 was classified as class III $(25-50 \mathrm{mg} / \mathrm{L})$ and ST5 was classified as class IV $(50-100 \mathrm{mg} / \mathrm{L})$. Based on the statistical analysis, there was a significant difference in COD value between two sampling times with a $p$-value $=0.027$, especially at ST1 and ST5, and there was a significant different between each sampling station with a $p$-value $=0.03$ and the total SD was 39.69. COD was the amount of oxygen required to oxidize organic chemicals found in the water. High COD occurs due to the high organic and inorganic materials presence. When the concentration of organic matter in water increased, the COD value was also increased. Increase of chemical organic materials in water samples at ST1 and ST5 due to the disposal of solid waste into water was one of the contributors to the decline in water quality and DO which indicated by the presence of organic and inorganic materials.

The average TSS for all sampling stations at two sampling times was between $0.005 \mathrm{~g} / \mathrm{L}$ to $0.041 \mathrm{~g} / \mathrm{L}$. Most stations were classified as class I ( $<25 \mathrm{mg} / \mathrm{L})$ according to WQI, except for ST2, it was classified as class II $(25-50 \mathrm{mg} / \mathrm{L})$. From the one-way ANOVA analysis, it was found that there was no significant difference in TSS between the two sampling times for all stations with a $p$-value $=0.342(p>0.05)$ and the $\mathrm{SD}=0.006$. The total SD for all stations was 0.02. High TSS content was due to the land development activities, mining and erosion activities ranging from mud, waste mineral, fine particles of sand silt and clay. High TSS can affects the metabolism and physiology of various organisms such as fish and aquatics organisms. They were products of run off TSS which increased with the increased of rainfall. Substances presence in the air also affected the rainfall characteristics. Water containing suspended solids and organic matter generally showed high turbidity. Heavy rainfall as in first sampling was the important factor for the reduction of contamination in the atmosphere (Kemker, 2014).

The average of $\mathrm{NH}_{3}-\mathrm{N}$ for all sampling stations was range between $1.54 \mathrm{mg} / \mathrm{L}$ to $3.15 \mathrm{mg} / \mathrm{L}$. The average $\mathrm{NH}_{3}-\mathrm{N}$ value of ST2 shows the highest value of $4.65 \mathrm{mg} / \mathrm{L}$ which was at the first sampling. The average value of $\mathrm{NH}_{3}-\mathrm{N}$ at ST5 was the lowest with a value of $1.12 \mathrm{mg} / \mathrm{L}$ at the second sampling. For ST1, ST2 and ST3, the $\mathrm{NH}_{3}-\mathrm{N}$ were classified in class V $(>2.7 \mathrm{mg} / \mathrm{L})$ and ST4 and ST5 was classified in class IV $(0.9-2.7 \mathrm{mg} / \mathrm{L})$. One-way ANOVA analysis shows no significant difference in $\mathrm{NH}_{3}-\mathrm{N}$ between two sampling times with a $p$-value of $0.153(p>0.05)$, and there was no significant within stations with a $p$-value $=0.134(p>0.05)$ and the total SD was 1.1583. High concentration of ammonium nitrogen in water can threaten aquatic life, especially in terms of respiration rate and increases pulse rate according to Halim et al. (2017). The higher value of 
ammonium nitrogen and other organic substances in water was most probably due to the untreated domestic sewage, waste materials and faeces.

\section{Heavy Metals Content}

A total of 19 heavy metals content including aluminum (Al), Arsenic (As), Barium $(\mathrm{Ba})$, Beryllium $(\mathrm{Be})$, Calcium $(\mathrm{Ca})$, Cadmium $(\mathrm{Cd})$, Cobalt $(\mathrm{Co})$, Chromium $(\mathrm{Cr})$, Copper $(\mathrm{Cu})$, Iron $(\mathrm{Fe})$, Potassium $(\mathrm{K})$, Lithium $(\mathrm{Li})$, Magnesium $(\mathrm{Mg})$, Manganese $(\mathrm{Mn})$, Sodium ( $\mathrm{Na})$, Nickel (Ni), Lead (Pb), Zinc ( $\mathrm{Zn}$ ) and Mercury ( $\mathrm{Hg}$ ) were measured during two sampling times at all five sampling stations of Klang River (Table 3).

Table 3. Heavy metals concentration ( $p p b$ ) at five sampling stations for two sampling times

\begin{tabular}{|c|c|c|c|c|c|c|c|c|c|c|}
\hline \multirow{2}{*}{$\begin{array}{r}\text { Metals } \\
(\mathbf{p p b})\end{array}$} & \multicolumn{2}{|c|}{ ST1 } & \multicolumn{2}{|c|}{ ST2 } & \multicolumn{2}{|c|}{ ST3 } & \multicolumn{2}{|c|}{ ST4 } & \multicolumn{2}{|c|}{ ST5 } \\
\hline & \begin{tabular}{|c|} 
First \\
sampling
\end{tabular} & $\begin{array}{c}\text { Second } \\
\text { sampling }\end{array}$ & $\begin{array}{c}\text { First } \\
\text { sampling }\end{array}$ & $\begin{array}{c}\text { Second } \\
\text { sampling }\end{array}$ & $\begin{array}{c}\text { First } \\
\text { sampling }\end{array}$ & $\begin{array}{c}\text { Second } \\
\text { sampling }\end{array}$ & $\begin{array}{c}\text { First } \\
\text { sampling }\end{array}$ & $\begin{array}{c}\text { Second } \\
\text { sampling }\end{array}$ & $\begin{array}{c}\text { First } \\
\text { sampling }\end{array}$ & $\begin{array}{c}\text { Second } \\
\text { sampling }\end{array}$ \\
\hline $\mathrm{Al}$ & 17.91 & 23.31 & 56.73 & 7.54 & 12.14 & 7.21 & 6.89 & 4.13 & 26.69 & 14.01 \\
\hline As & 50.81 & 74.37 & 51.12 & 64.25 & 51.86 & 65.85 & 47.42 & 50.26 & 44.2 & 40.49 \\
\hline $\mathrm{Ba}$ & 104.8 & 230.08 & 109.21 & 249.71 & 101.5 & 263.08 & 106.43 & 284.69 & 124.83 & 287.24 \\
\hline $\mathrm{Be}$ & 0.02 & 0.05 & 0.01 & 0.02 & 0.01 & 0.01 & 0.01 & 0.02 & 0.03 & 0.019 \\
\hline $\mathrm{Ca}$ & 3454.99 & 2973.44 & 3681.42 & 2914.67 & 3617.17 & 3054.07 & 3880.95 & 3506.33 & 4741.87 & 4194.6 \\
\hline $\mathrm{Cd}$ & 0.05 & 0.35 & 0.02 & 0.11 & 0.019 & 0.23 & 0.03 & 0.06 & 0.03 & 0.05 \\
\hline Co & 0.23 & 0.21 & 0.12 & 0.14 & 0.11 & 0.12 & 0.13 & 0.13 & 0.19 & 0.21 \\
\hline $\mathrm{Cr}$ & 3.52 & 3.29 & 4.8 & 2.55 & 3.81 & 2.33 & 3.87 & 2.43 & 3.65 & 2.27 \\
\hline $\mathrm{Cu}$ & 2.03 & 2.36 & 1.44 & 2.65 & 1.91 & 2.28 & 1.27 & 1.93 & 2.12 & 1.6 \\
\hline $\mathrm{Fe}$ & 115.9 & 354.58 & 125.21 & 287.05 & 107.81 & 313.02 & 86.86 & 363.63 & 110.44 & 249.54 \\
\hline K & 5355.36 & 9901.15 & 5544.69 & 9887.01 & 5545.81 & 8330.59 & 5886.77 & 9638.96 & 6078.4 & 12388.8 \\
\hline $\mathrm{Li}$ & 1.09 & 1.25 & 1.21 & 1.25 & 1.16 & 1.23 & 1.23 & 1.31 & 1.63 & 1.61 \\
\hline $\mathrm{Mg}$ & 1635.42 & 2459.74 & 1742.29 & 2721.56 & 1700.41 & 2239.62 & 1924.03 & 2626.13 & 1977.16 & 2444.02 \\
\hline $\mathrm{Mn}$ & 1.51 & 0.85 & 3.81 & 0.21 & 0.95 & 0.11 & 1.35 & 0.33 & 3.03 & 0.09 \\
\hline $\mathrm{Na}$ & 16326.7 & 19628.8 & 17167.7 & 20686.9 & 17216.3 & 19397.8 & 18520.3 & 22116.1 & 18065.1 & 21763.8 \\
\hline $\mathrm{Ni}$ & 1.43 & 1.79 & 1.57 & 1.47 & 1.22 & 1.32 & 1.32 & 1.52 & 1.66 & 2.3 \\
\hline $\mathrm{Pb}$ & 1.6 & 0.03 & 0.47 & 0.37 & 0.08 & 1.32 & 0.07 & 0.01 & 0.08 & 0.02 \\
\hline $\mathrm{Zn}$ & 30.24 & 34.55 & 29.15 & 12.37 & 22.79 & 35.52 & 21.67 & 16.12 & 21.32 & 14.1 \\
\hline $\mathrm{Hg}$ & 0.75 & 0.88 & 0.19 & 0.25 & 0.16 & 0.26 & 0.11 & 0.16 & 0.35 & 0.56 \\
\hline
\end{tabular}

Table 3 shows the average of heavy metals content at the five sampling stations for two sampling times. The unit used for heavy metals concentration in this study was $1 \mathrm{ppb}$ which equal to $0.001 \mathrm{mg} / \mathrm{L}$.

The average of $\mathrm{Al}$ concentrations during the two sampling times were $20.61 \mathrm{ppb}$, $32.14 \mathrm{ppb}, 9.68 \mathrm{ppb}, 5.52 \mathrm{ppb}$ and $20.35 \mathrm{ppb}$ for ST1, ST2, ST3, ST4 and ST5, respectively. The concentration of Al classified by WQI as class II $(<0.06 \mathrm{mg} / \mathrm{L})$. For As, the mean concentration value of two sampling times at ST1 was $62.591 \mathrm{ppb}$ $(0.0626 \mathrm{mg} / \mathrm{L})$ which shows a maximum value and ST5 has the lowest mean concentration of As which was $42.346 \mathrm{ppb}$. The mean concentration of As classified by WQI class as class III ( $>0.05 \mathrm{mg} / \mathrm{L})$. The mean concentration of Ba of two sampling times were $167.44 \mathrm{ppb}, 179.47 \mathrm{ppb}, 182.29 \mathrm{ppb}, 195.56 \mathrm{ppb}$ and $206.04 \mathrm{ppb}$ for ST1, ST2, ST3, ST4 and ST5, respectively. It was found that the maximum mean concentration of Ba was at ST5 and the lowest was at ST4. The mean concentration of Ba classified by WQI as class I $(<1 \mathrm{mg} / \mathrm{L})$. For Be, the mean concentration of two sampling times was $0.041 \mathrm{ppb}$, 
$0.02 \mathrm{ppb}, 0.015 \mathrm{ppb}, 0.021 \mathrm{ppb}$ and $0.025 \mathrm{ppb}$ for ST1, ST2, ST3, ST4 and ST5, respectively. The mean concentration of Be classified by WQI as class I ( $<0.05 \mathrm{mg} / \mathrm{L})$. It was indicated that, in this study, the mean concentration of Be was the lowest among the 19 heavy metals. The mean concentration of $\mathrm{Ca}$ which was the third highest after $\mathrm{Na}$ and K during two sampling times has the value of $3214.22 \mathrm{ppb}$ at ST1, 3298.05 ppb at ST2, $3335.62 \mathrm{ppb}$ at ST3, $3693.64 \mathrm{ppb}$ at ST4 and $4468.24 \mathrm{ppb}$ at ST5. The highest mean concentration of Ca was at ST5 and the lowest was at ST1. The mean concentration of Ca classified by WQI as class I.

The mean concentration of $\mathrm{Cd}$ of two sampling times has the second lowest value. The value was $0.21 \mathrm{ppb}, 0.06 \mathrm{ppb}, 0.13 \mathrm{ppb}, 0.05 \mathrm{ppb}$ and $0.05 \mathrm{ppb}$ for ST1, ST2, ST3, ST4 and ST5, respectively. The mean concentration of Cd classified by WQI was at class I $(<0.001 \mathrm{mg} / \mathrm{L})$. For $\mathrm{Co}$, the mean concentration value at ST1 was $0.23 \mathrm{ppb}$ $(0.00023 \mathrm{mg} / \mathrm{L}), \mathrm{ST} 2=0.13 \mathrm{ppb}, \mathrm{ST} 3=0.12 \mathrm{ppb}, \mathrm{ST} 4=0.13 \mathrm{ppb}$ and ST5 $=0.21 \mathrm{ppb}$. The mean concentration of Co classified by WQI as class I. For Cr, the mean concentration value of two sampling times was $3.41 \mathrm{ppb}, 3.68 \mathrm{ppb}, 3.07 \mathrm{ppb}, 3.16 \mathrm{ppb}$ and $2.97 \mathrm{ppb}$ for ST1, ST2, ST3, ST4 and ST5, respectively. Maximum mean concentration of $\mathrm{Cr}$ was recorded at ST2 and the lowest was at ST5. The mean concentration of $\mathrm{Cr}$ classified by WQI as class I $(<0.05 \mathrm{mg} / \mathrm{L})$. Cu mean concentration of two sampling times at ST1 was $2.20 \mathrm{ppb}, \mathrm{ST} 2=2.05 \mathrm{ppb}, \mathrm{ST} 3=2.10 \mathrm{ppb}, \mathrm{ST} 4=1.60 \mathrm{ppb}$ and ST5 $=1.86 \mathrm{ppb}$. The mean concentration of $\mathrm{Cu}$ classified by WQI as class I $(<0.02 \mathrm{mg} / \mathrm{L})$. For Fe, the mean concentration value of two sampling times was 235.24 ppb, $206.13 \mathrm{ppb}, 210.42 \mathrm{ppb}, 225.25 \mathrm{ppb}$ and $179.99 \mathrm{ppb}$ for ST1, ST2, ST3, ST4 and ST5, respectively. The mean concentration of Fe classified by WQI as class I $(<1 \mathrm{mg} / \mathrm{L})$. K has the second highest mean concentration after $\mathrm{Na}$ which the value for ST1, ST2, ST3, ST4 and ST5 was $7628.26 \mathrm{ppb}, 7715.85 \mathrm{ppb}, 6938.2 \mathrm{ppb}, 7762.87 \mathrm{ppb}$ and $9233.6 \mathrm{ppb}$, respectively. The mean concentration of K classified by WQI as class I.

The recorded mean concentration of two sampling times for Li was $1.17 \mathrm{ppb}, 1.23 \mathrm{ppb}$, $1.20 \mathrm{ppb}, 1.27 \mathrm{ppb}$ and $1.63 \mathrm{ppb}$ for ST1, ST2, ST3, ST4 and ST5, respectively. The mean concentration of Li classified by WQI as class I. Mg mean concentration of two sampling times showed the values of $2047.58 \mathrm{ppb}$ at ST1, $2231.9 \mathrm{ppb}$ at ST2, 1970.02 ppb at ST3, $2275.08 \mathrm{ppb}$ at ST4 and $2210.68 \mathrm{ppb}$ at ST5. The mean concentration of Mg classified by WQI as class I. For Mn, the mean concentration value was $1.18 \mathrm{ppb}, 2.02 \mathrm{ppb}$, $0.53 \mathrm{ppb}, 0.84 \mathrm{ppb}$ and $1.57 \mathrm{ppb}$ for ST1, ST2, ST3, ST4 and ST5, respectively. Maximum mean concentration of Mn was at ST2 and the lowest mean was at ST3. The mean concentration of Mn classified by WQI as class II $(<0.1 \mathrm{mg} / \mathrm{L})$. Na has the highest mean concentration among the 19 heavy metals. The recorded values for ST1 was $17977.8 \mathrm{ppb}$ which was the lowest mean, ST2 $=18927.3 \mathrm{ppb}$, ST3 $=18307.1 \mathrm{ppb}$, ST4 $=20318.2 \mathrm{ppb}$, which was the highest value and ST5 $=19914.5 \mathrm{ppb}$. The mean concentration of $\mathrm{Na}$ classified by WQI as class I. The mean concentration value for $\mathrm{Ni}$ was $1.61 \mathrm{ppb}, 1.52 \mathrm{ppb}, 1.28 \mathrm{ppb}, 1.42 \mathrm{ppb}$ and $1.98 \mathrm{ppb}$ for ST1, ST2, ST3, ST4 and ST5, respectively. The mean concentration of Ni classified by WQI class as class II $(<0.05 \mathrm{mg} / \mathrm{L})$. For $\mathrm{Pb}$, the mean concentration value of two sampling times at ST1 was $0.82 \mathrm{ppb}, \mathrm{ST} 2=0.42 \mathrm{ppb}, \mathrm{ST} 3=0.70 \mathrm{ppb}, \mathrm{ST} 4=0.05 \mathrm{ppb}$ and ST5 $=0.05 \mathrm{ppb}$. The mean concentration of Pb classified by WQI as class III $(<0.02 \mathrm{mg} / \mathrm{L})$.

$\mathrm{Zn}$ has the mean concentration values of two sampling times of $32.40 \mathrm{ppb}, 20.76 \mathrm{ppb}$, $29.16 \mathrm{ppb}, 18.90 \mathrm{ppb}$ and $17.71 \mathrm{ppb}$ for ST1, ST2, ST3, ST4 and ST5, respectively. The mean concentration of $\mathrm{Zn}$ classified by WQI as class I $(<0.4 \mathrm{mg} / \mathrm{L})$. For $\mathrm{Hg}$, the mean concentration recorded for ST1 was 0.89 ppb which was the highest value, for ST2 was 
$0.26 \mathrm{ppb}$, ST3 was $0.27 \mathrm{ppb}$, for ST4 was $0.17 \mathrm{ppb}$ which was the lowest value, and ST5 was $0.57 \mathrm{ppb}$. The mean concentration of Na classified by WQI as class III $(0.0001 \mathrm{mg} / \mathrm{L})$. Most of the sources of heavy metals were from wastes and effluents that were being discharged into the river (Awotedu and Ogunbamowo, 2019). The high concentration of heavy metals was primarily owing to the industrial pollution. Heavy metals in the urban atmosphere were mainly derived from industrial activities (i.e. mining, smelting and fossil fuel combustion), traffic emissions (i.e. vehicle exhausts and the products of wear from tires, brake linings and bearings) and natural minerals sources, forest fires and oceans (Geiger and Cooper, 2010; Ismail and Hanafiah, 2019). According to Tunca et al. (2017), heavy metals have a significant threat to human health as it can accumulate in living organisms. The results showed that most of the heavy metals detected were in satisfactory with the standard for water and packaged drinking water as stated in Drinking Water Quality Standards for Malaysia by DOE.

\section{Total Coliform and Fecal Coliform}

The present of total coliform bacteria and fecal coliform, E. coli in Klang River was in the range of 102 to $105 \mathrm{cfu} / 100 \mathrm{~mL}$. The coliform bacteria group consist of several genera of bacteria belonging to the family Enterobacteriaces including Enterobacter, Escherichia, Shigella, Salmonella, Protus and Klebsiella. Most bacteria of this group mainly live in water from digestive system of human and animal, which can be as an indicator for polluted water with domestic untreated wastewater. An appropriate value of water sample was serially diluted with sterile normal saline in order to get countable colonies. Colony count of fecal coliform by bacterial counter chamber as shown in Figure $3 a$ Luria agar and Figure $3 b$ Luria broth.

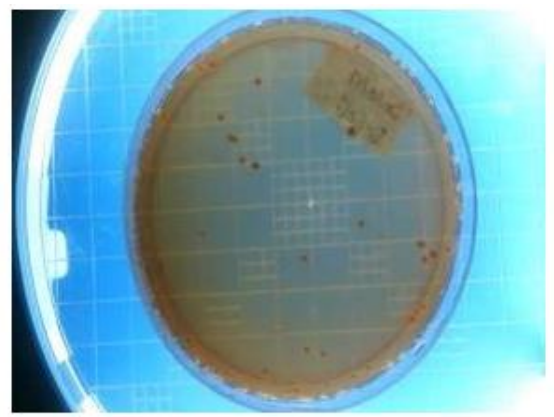

(a)

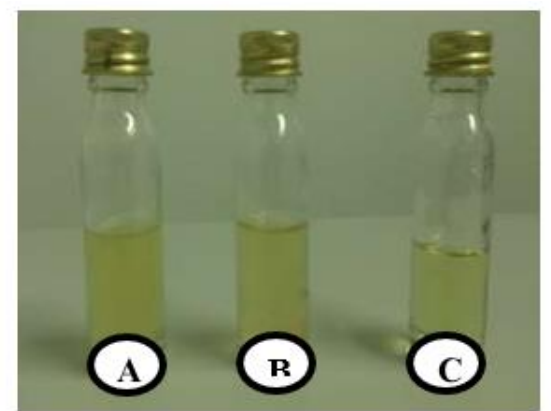

(b)

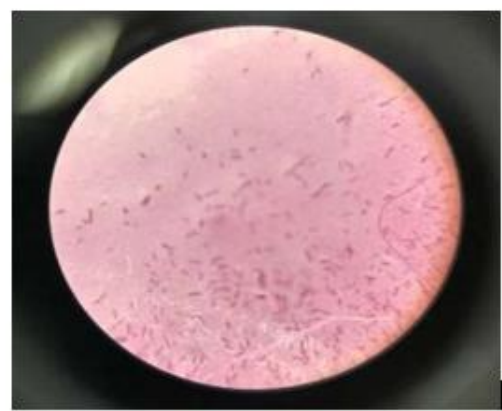

(c)

Figure 3. Fecal coliform (E. coli) on (a) Luria agar and (b) Luria broth where E. Coli diluted in, A) 10-1, B) 10-2, C) negative; and (c) Gram negative short rod E. coli under light microscopy 
Figure $3 b$ showed the growth of fecal coliform (E. coli) in diluted 10-1, 10-2 and negative (control Luria broth only) as A, B and C, respectively. Total coliform bacteria presented in water samples at ST1, ST2 and ST3 was higher than in the water samples at ST4 and ST5. Range of total coliform in the Klang River was from 7 x 102 CFU/100 mL to $2.5 \times 104 \mathrm{CFU} / 100 \mathrm{~mL}$. The total coliform for ST1 was about $17500 \mathrm{CFU} / 100 \mathrm{~mL}$, ST2 was $11300 \mathrm{CFU} / 100 \mathrm{~mL}$ and ST3 was $10700 \mathrm{CFU} / 100 \mathrm{~mL}$, which showed a higher count of total coliform among other stations as shown in Figure 4. The total coliform at ST4 was about $4900 \mathrm{CFU} / 100 \mathrm{~mL}$ and ST5 was $4200 \mathrm{CFU} / 100 \mathrm{~mL}$. According to INWQS for Malaysia, the level of total fecal coliform for recreational water is $400 / 100 \mathrm{~mL}$ and total coliform is $5000 / 100 \mathrm{~mL}$ which classified as class II.

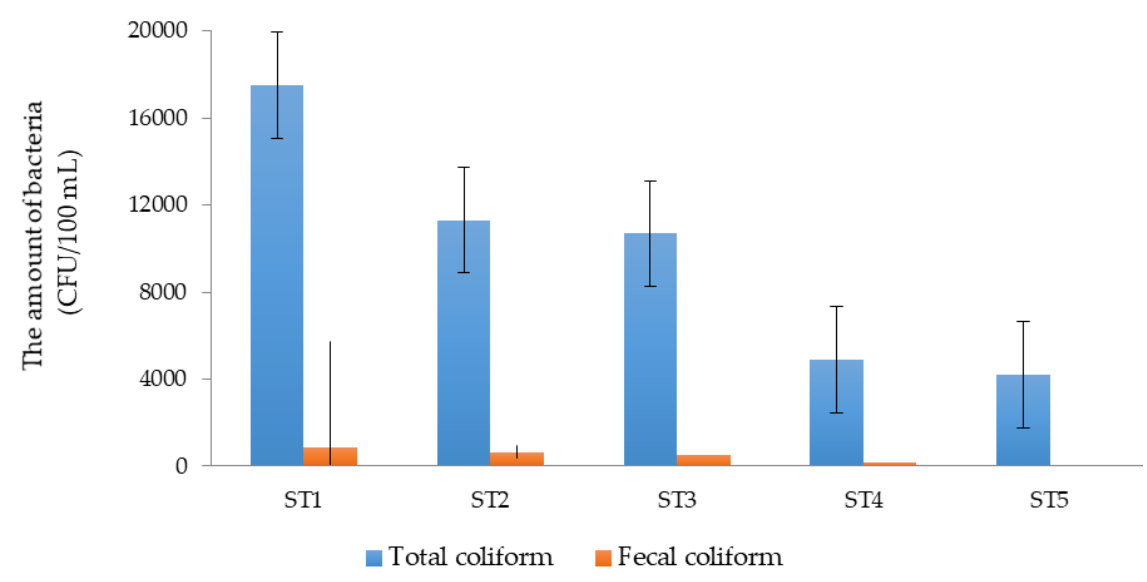

Figure 4. Total coliform and fecal coliform at all stations

Not all coliform is associated with the intestinal tract, some genera occur widely in nature (e.g. Enterobacter spp. associated with plant materials) while some fecal coliform may flourish in diverse environments outside the intestinal tract. However, a high number of total coliform in the Klang River may indicated the present of other pathogenic microorganisms that may cause illness. Coliform bacteria have been used as indicator of unsanitary conditions in water and foods for over century. The one-way ANOVA test showed that there were significant differences $(p<0.05)$ for total coliform concentrations in the water between five stations and Klang River was classified in class III for ST1, ST2 and ST3 based on the INWQS.

Fecal coliform bacteria, which belong to Enterobacteriaces, were presented in large number in the feces and intestinal tracts of human and other warm-blooded animals, and can enter river water from human and animal's wastes. If a large number of fecal coliform bacteria (over 400 colonies $/ 100$ milliliters $(\mathrm{mL})$ of water sample) are found in water, it is possible that pathogenic microorganisms are also present in the river water. E. coli, a gram negative short rod with negative oxidase reactions was chosen as an indicator for fecal pollution (Figure 3c). E. coli was presented at all time of sampling at Klang River indicating that the water was contaminated by fecal materials from humans. The number of fecal coliform presence in the river varies, some were not detected at 103 dilutions at ST4 and 5 and to maximum value of 3.4 x $103 \mathrm{CFU} / 100 \mathrm{~mL}$. Stations with higher count of $E$. coli were ST1, ST2 and ST3 as shown in Figure 4.

According to INWQS for Malaysia, the level of fecal coliform for recreational water is $400 / 100 \mathrm{~mL}$ and total coliform is $5000 / 100 \mathrm{~mL}$ which classified as class III. ST1, ST2 
and ST3 of Klang River were acceded the standard permitted level determined by DOE Malaysia. E. coli, Salmonella and other Enterobacteriaces bacteria were also found in the river with higher level especially at ST1, ST2 and ST3. ST4 and ST5 were classified as class II. Statistical analysis of coliform which tested by one-way ANOVA test showed there were significant differences with $p$-value, $p=0.03$ for fecal coliform concentrations in the water between five stations with the SD of 0.26. Meanwhile there were no significant differences between the sampling times of all stations with $p>0.05$. In the study conducted by Balleste et al. (2020), they found that fecal pollution was caused by humans and animals wastes, domestic effluent, improper sanitation systems and land use of agricultural area.

Samples of ST1, ST2 and ST3 were more polluted by total and fecal coliform bacteria and not suitable for activities related to body contact or for fish farming. All stations received untreated human wastes which was discharged from condominiums, small manufactures, restaurants and malls complexes nearby. This may cause the higher count of total and fecal bacteria at these areas. Swimming and fishing in a river water with high levels of fecal coliform bacteria will increase the chance of developing illness (fever, nausea, diarrhea or stomach cramps) from pathogenic entering the fish body and human body through the mouth, nose, ears or injury of skin. Diseases and illnesses that can be contacted in water with high fecal coliform counts include typhoid fever, hepatitis, gastroenteritis and dysentery and ear indications. Fecal coliform, like other bacteria, can usually be killed by boiling water or by treating it with chlorine. Washing thoroughly with soap after contact with contaminated water can also help prevent indications according to APHA (1998).

\section{Phytoremediation by Pistia stratiotes and Lemna minor $L$.}

There were eight high toxic heavy metals which have been tested in the phytoremediation of river water samples using Pistia stratiotes and Lemna minor L. The value was taken on the $0,7,14$ and 21 days of experiment. Figures 5 and 6 show the heavy metals concentration in the phytoremediation test using Pistia stratiotes and Lemna minor L., respectively.

Based on the figures, Pistia stratiotes and Lemna minor L. can reduced the concentration of heavy metals in the river water samples from day 7 until day 21 at each sampling station. The average of initial value of As was ranged between $40.49 \mathrm{ppb}$ at ST5 and $74.37 \mathrm{ppb}$ at ST1. The As concentration in the river for all stations was ranged from $3.89 \mathrm{ppb}$ at ST5 to $5.11 \mathrm{ppb}$ at ST1 after 7 days of treatment with Pistia stratiotes. On day 14 of the experiment, the concentration of As was reduced to as low as $2.26 \mathrm{ppb}$ at ST2 and the value was continue to decrease to $2.17 \mathrm{ppb}$ on day 21. It was found that there was a significant decreased of As concentration after 7 days. However, the phytoremediation became slower after 14 days at all stations. The statistical analysis showed that there was a significant difference of As level between stations and there was also a significant difference between sampling times and all the stations were classified as Class II. The standard deviation (SD) for ST2 and ST3 was 0.57 and 0.61 , respectively which show a high significant with a $p$-value of $p<0.05$. For the phytoremediation by Lemna minor L., the As concentration ranged was from $40.26 \mathrm{ppb}$ at ST5 to $67.55 \mathrm{ppb}$ at ST1 on day 7 of treatment. The average level of As was decreased slightly to $67.23 \mathrm{ppb}$ $(0.067 \mathrm{mg} / \mathrm{L})$ according to WQI with a standard of $0.05 \mathrm{mg} / \mathrm{L}$ at ST1 and to $40.05 \mathrm{ppb}$ at ST5 after 14 days of phytoremediation. After 21 days of phytoremediation the As value was slightly decreased to $40.003 \mathrm{ppb}$ at ST5 while the value was $66.211 \mathrm{ppb}$ at ST1. It 
can be deduced that, the As concentration was slightly decreased at all stations. The statistical analysis showed that there was a significant difference of As level between stations and there was no significant difference between sampling times and all the stations was categorized as Class II. The SD for ST1 and ST3 was 3.73 and 3.07, respectively which show a high significant with a $p$-value of $p=0.001$.
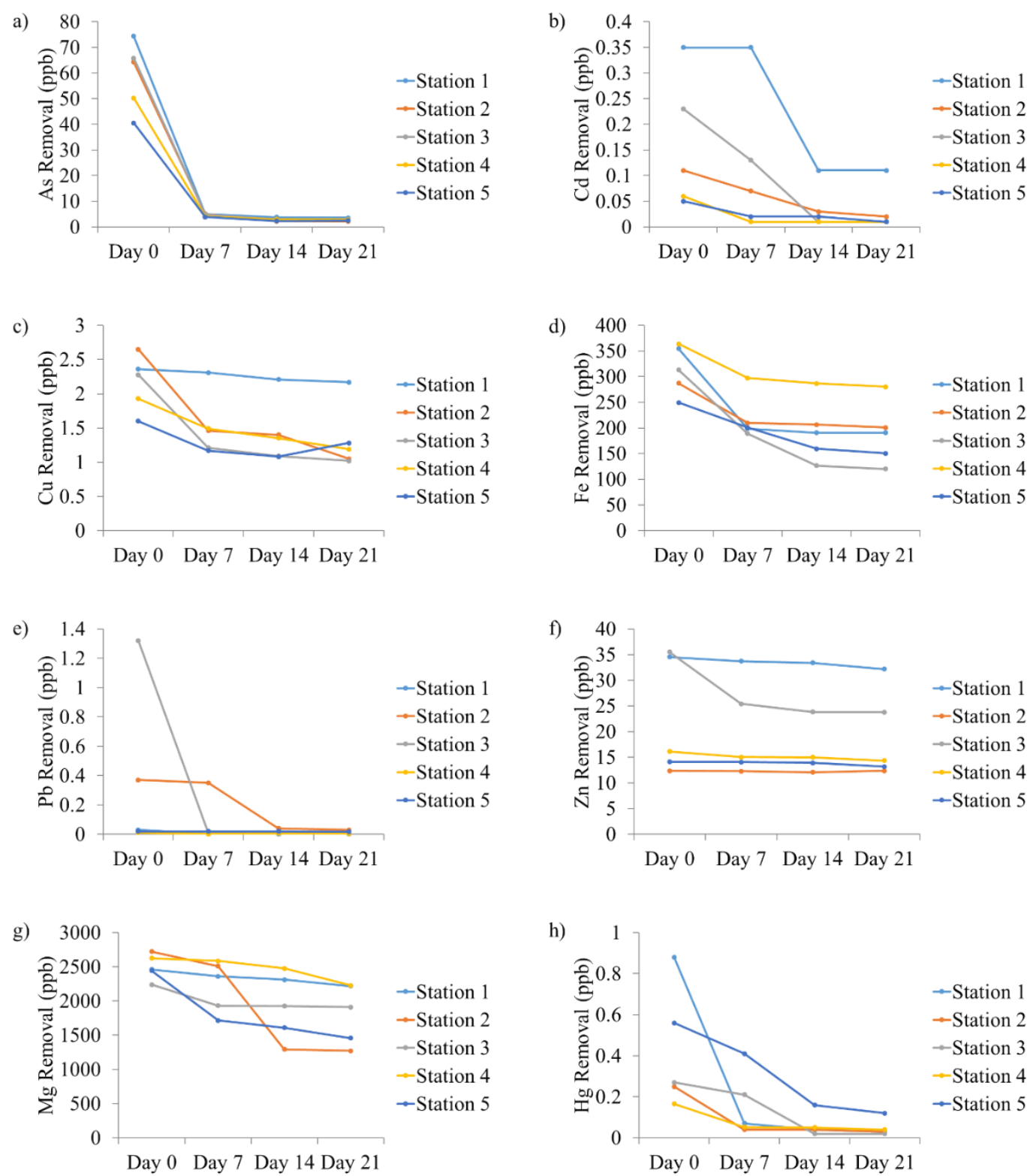

Figure 5. Heavy metals removal for a) $\mathrm{As}, b) \mathrm{Cd}$, c) $\mathrm{Cu}, \mathrm{d}$ ) $\mathrm{Fe}, \mathrm{e}) \mathrm{Pb}, \mathrm{f}) \mathrm{Zn}, \mathrm{g}) \mathrm{Mg}$ and $\mathrm{h}) \mathrm{Hg}$ by Pistia stratiotes

The average of initial concentration of Cd was ranged between $0.05 \mathrm{ppb}$ at ST5 to $0.35 \mathrm{ppb}$ at ST1. After 7 days of treatment with Pistia stratiotes, the Cd concentration reduced to $0.01 \mathrm{ppb}$ at ST4 and to $0.35(0.0007 \mathrm{mg} / \mathrm{L})$ at $\mathrm{ST} 1$. The average level of Cd was $0.011 \mathrm{mg} / \mathrm{L}$ according to WQI. On day 21, the lowest value of $\mathrm{Cd}$ was recorded at ST3, ST4 and ST5 which was $0.01 \mathrm{ppb}$. Statistical analysis showed that there was a 
significant difference of Cd level between all stations which the $p$-value was $p=0.023$. Meanwhile at all stations there was no significant difference between sampling times with $p$-value of $p>0.05$ and all stations was classified as Class III. It was noticed that there was a high decreased of $\mathrm{Cd}$ after phytoremediation treatment by Pistia stratiotes for all stations. For the phytoremediation by Lemna minor L., on day 7, the Cd concentration for all stations was ranged from $0.04 \mathrm{ppb}$ at ST4 to $0.35 \mathrm{ppb}(0.0007 \mathrm{mg} / \mathrm{L})$ at ST1. The average level of Cd was $0.011 \mathrm{mg} / \mathrm{L}$ according to WQI. Based on the statistical analysis that has been performed, it was indicated that there was a significant difference of $\mathrm{Cd}$ level between all stations which the $p$-value was $p=0.034$. Meanwhile at ST1, there was a significant difference between sampling times with a $p$-value of $p<0.05$ and all stations was classified as Class III especially after 14 days of treatment. It was found that there was a high decreased of $\mathrm{Cd}$ after phytoremediation for all stations.
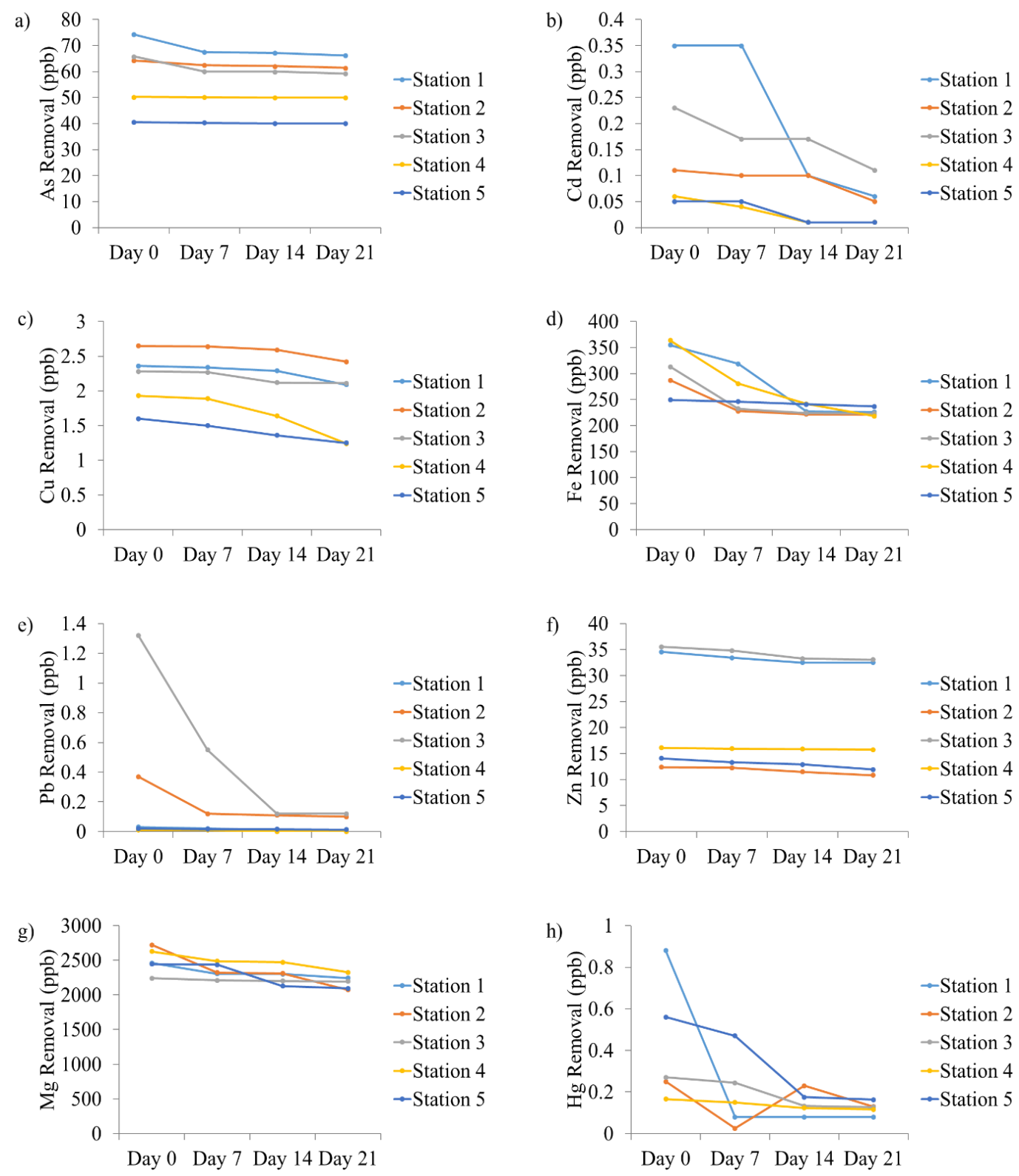

Figure 6. Heavy metals removal for a) $\mathrm{As}, \mathrm{b}$ ) $\mathrm{Cd}$, c) $\mathrm{Cu}, \mathrm{d}$ ) $\mathrm{Fe}, \mathrm{e}) \mathrm{Pb}, \mathrm{f}) \mathrm{Zn}, \mathrm{g}) \mathrm{Mg}$ and $\mathrm{h}) \mathrm{Hg}$ by Lemna minor $L$. 
The concentration of $\mathrm{Cu}$ has a ranged of initial value between 1.60 at ST5 and 2.65 at ST2. In the phytoremediation by Pistia stratiotes, the concentration of $\mathrm{Cu}$ showed a decreasing value on day 7, 14 and 21 for all stations. $\mathrm{Cu}$ concentration was reduced to between $1.02 \mathrm{ppb}$ at ST3 to $2.17 \mathrm{ppm}(0.0023 \mathrm{mg} / \mathrm{L})$ at ST1 after 21 days of treatment. The average level of $\mathrm{Cu}$ was $0.012 \mathrm{mg} / \mathrm{L}$ according to WQI which was classified as class III. The results of statistical analysis showed that there was a significant difference of $\mathrm{Cu}$ levels between stations with $p$-value $=0.001$ and a standard deviation of 0.59 and there was no significant difference between sampling times with $p>0.05$. Lemna minor L. was also able to reduce the concentration of $\mathrm{Cu}$ in the river water samples for all stations. On day 21 of treatment, the concentration of $\mathrm{Cu}$ was reduced to as low as $1.24 \mathrm{ppb}$ which at ST4. The average level of $\mathrm{Cu}$ was $0.012 \mathrm{mg} / \mathrm{L}$ according to WQI which was classified as class III. It can be deduced that the phytoremediation by Lemna minor L. showed a slightly decreased in the average level of $\mathrm{Cu}$ concentration from day 7 until day 21 . Based on the statistical analysis conducted, it was found that there was a significant difference of $\mathrm{Cu}$ levels between stations with $\mathrm{p}$-value $=0.002$ and the total SD was 0.46 . There was also a significant difference between sampling times with $\mathrm{p}<0.05$.

By means of Fe, the average initial concentration for all stations was between $249.54 \mathrm{ppb}$ (ST5) and $363.63 \mathrm{ppb}$ (ST4). The treatment of river water samples with Pistia stratiotes showed that the concentration level of Fe was slightly decreased from day 7 until day 21 . After 21 days of treatment, the concentration of Fe at all stations was ranged from $119.99 \mathrm{ppb}$ at ST3 to $280.33 \mathrm{ppb}(0.280 \mathrm{mg} / \mathrm{L})$ at ST4. According to WQI, the average level of Fe content should be $1 \mathrm{mg} / \mathrm{L}$ and classified as class II. The one-way ANOVA test showed a significant difference between the Fe concentrations for all stations especially samples for ST1, ST2 and ST3 compared to others stations with $p$-value of $p=0.001$ and the total SD of 0.21 . The Fe concentration in water samples was also slightly decreased from day 7 until day 21 when treated with Lemna minor L. The concentration of Fe was reduced to a lowest value of $218.27 \mathrm{ppb}$ at ST4 and highest value of $237 \mathrm{ppb}$ at ST5 after 21 days of treatment. The average level of Fe was $1 \mathrm{mg} / \mathrm{L}$ according to WQI and classified as class II. According to the one-way ANOVA test that has been performed, it showed that there was a significant difference between the Fe concentrations for all stations especially for ST1, ST2, ST3 and ST4 compared to ST5 with $p$-value $p=0.001$ and the standard deviation was 47.41 .

For $\mathrm{Pb}$, the recorded average of initial concentration of $\mathrm{Pb}$ for all stations was between $0.01 \mathrm{ppb}$ at ST4 and $1.32 \mathrm{ppb}$ at ST3. In the phytoremediation by Pistia stratiotes, it was indicated that the concentration level of $\mathrm{Pb}$ was decreased on day 7, 14 and 21 of treatment. The $\mathrm{Pb}$ concentration for all stations was ranged from $0.001 \mathrm{ppb}$ at ST1 to 0.03 at ST2 after 21 days. The average level of $\mathrm{Pb}$ was $0.02 \mathrm{mg} / \mathrm{L}$ according to WQI which indicates that the river was not polluted by $\mathrm{Pb}$. The statistical analysis by one-way ANOVA test showed that there was no significant difference between the five stations and phytoremediation times with a $p$-value of $p>0.05$. All stations were classified as Class II. As for the treatment by Lemna minor L., the level of $\mathrm{Pb}$ concentration was also decreased from day 7 until day 21. After 21 days of treatment, the Pb concentration at ST4 showed the lowest final value which was $0 \mathrm{ppb}$. The average level of $\mathrm{Pb}$ was $0.02 \mathrm{mg} / \mathrm{L}$ according to WQI which indicates that the river was not polluted by $\mathrm{Pb}$. The statistical analysis by ANOVA test showed that there was a significant difference between ST2 and ST3 for phytoremediation times with $p$-value $p<0.029$ but there was no significant for other stations. All stations were therefore reported to be classified as Class II. 
$\mathrm{Zn}$ has the average of initial concentration for all stations of $12.37 \mathrm{ppb}$ at ST2 and $35.52 \mathrm{ppb}$ at ST3. For the phytoremediation by Pistia stratiotes, it was found that $\mathrm{Zn}$ concentration was slightly decreased from day 7 until day 21 . On day 21 , the $\mathrm{Zn}$ concentration for all stations was ranged from $12.35 \mathrm{ppb}$ at ST2 to $32.17(0.03 \mathrm{mg} / \mathrm{L})$. The average level of $\mathrm{Zn}$ was $0.4 \mathrm{mg} / \mathrm{L}$ according to WQI which indicated that the river was not polluted by $\mathrm{Zn}$. The range value of $\mathrm{Zn}$ in the river water recorded in all stations were classified as Class III. The one-way ANOVA test showed that there was no significant difference between the samples with sampling times for five stations with $p$-value $p=0.085$, while there was a significant difference between stations with a $p$-value of $p=0.002$ and the total SD was 16.44. The level of $\mathrm{Zn}$ concentration was also decreasing during the treatment with Lemna minor $\mathrm{L}$. The value of $\mathrm{Zn}$ concentration for all stations recorded on the 21 days of experiment was ranged from $10.85 \mathrm{ppb}$ at ST2 to $33.06 \mathrm{ppb}(0.03 \mathrm{mg} / \mathrm{L})$ at ST3. According to WQI, the average level of Zn was $0.4 \mathrm{mg} / \mathrm{L}$ which indicated that the river was not polluted by $\mathrm{Zn}$. Based on the reported $\mathrm{Zn}$ concentration, the river water area at all stations can be classified as Class III. Statistical analysis using one-way ANOVA test showed a significant difference between the samples for five stations with the $p$-value of $p<0.05$ and the total SD was 0.1 . There was also no significant difference between sampling times with $p$-value, $p>0.05$ and total SD of 10.44 .

As for $\mathrm{Mg}$, it was recorded that the average of its initial concentration for all stations was between $2444.02 \mathrm{ppb}$ at ST5 and $2626.12 \mathrm{ppb}$ at ST4. Pistia stratiotes was able to reduce the concentration of $\mathrm{Mg}$ in the phytoremediation of river water samples in this study. After 21 days of treatment the $\mathrm{Mg}$ concentration was reduced to $1272.81 \mathrm{ppb}$ at ST2 (which indicated the lowest value) and the value was approximately $2225.88 \mathrm{ppb}$ $(2.23 \mathrm{mg} / \mathrm{L})$ at ST4 (the highest value among the five stations). The average level of $\mathrm{Mg}$ was more than $5000 \mathrm{mg} / \mathrm{L}$ according to WQI which therefore indicated that the rivers in this study were in class I. The statistical analysis of one-way ANOVA test showed that there was no significant difference between the five stations with a $p$-value of $p>0.05$ and there was a significant difference between sampling times with $p=0.002$ and the total SD was 170.8, with slight effect of phytoremediation for this plant on $\mathrm{Mg}$ value. The $\mathrm{Mg}$ concentration also showed a reduction in its value when being treated using Lemna minor $\mathrm{L}$. After 21 days of treatment, the $\mathrm{Mg}$ concentration for all stations was ranged from $2073.44 \mathrm{ppb}$ at ST2 to $2326.94 \mathrm{ppb}(2.33 \mathrm{mg} / \mathrm{L})$ at ST4. The average level of $\mathrm{Mg}$ was more than $5000 \mathrm{mg} / \mathrm{L}$ as standardized in WQI. Hence, the rivers in this study can be classified as class I. The one-way ANOVA test showed that there was no significant difference between the five stations with a $p$-value of $p=0.86$ and there was a significant difference between sampling times with $p=0.002$. The total SD was 109.08, with slight effect of phytoremediation for this plant on $\mathrm{Mg}$ value.

$\mathrm{Hg}$ has the average of initial concentration which range between $0.17 \mathrm{ppb}$ at ST4 and $0.88 \mathrm{ppb}$ at ST1. The phytoremediation of river water samples by Pistia stratiotes showed a decreasing in the concentration of $\mathrm{Hg}$ on day 7, 14 and 21 of treatment. The final $\mathrm{Hg}$ concentration recorded a value from $0.02 \mathrm{ppb}$ at ST3 to $0.12 \mathrm{ppb}(0.00012 \mathrm{mg} / \mathrm{L})$ at ST5. The average level of $\mathrm{Hg}$ was $0.004 \mathrm{mg} / \mathrm{L}$ according to WQI. Thus, it was indicated that the water river was not polluted with $\mathrm{Hg}$ and all stations was classified as Class III. Based on the statistical analysis that has been performed, there was a significant difference between the five stations with a $p$-value of $p=0.008$. The total SD was 0.1 and there was a significant difference between sampling times with a $p$-value of $p=0.04$. When treated with Lemna minor, the $\mathrm{Hg}$ concentration was slightly decreased from day 7 until the end 
of experiment. On day 21 , the $\mathrm{Hg}$ concentration was reduced to a ranged of $0.08 \mathrm{ppb}$ at ST1 to $0.16 \mathrm{ppb}$ at ST5. According to WQI, the average level of $\mathrm{Hg}$ was $0.004 \mathrm{mg} / \mathrm{L}$. Thus, it was indicated that the water river was not polluted with $\mathrm{Hg}$ and all stations can be classified as Class III. The parametric one-way ANOVA test showed that there was a significant difference between the five stations with $p$-value, $p=0.02$ while the total SD was 0.13 especially for ST4 and there was no significant difference between sampling times with $p$-value $p=0.109$.

Figure 7 shows the heavy metals removal percentage in five sampling stations by Pistia stratiotes and Lemna minor L.

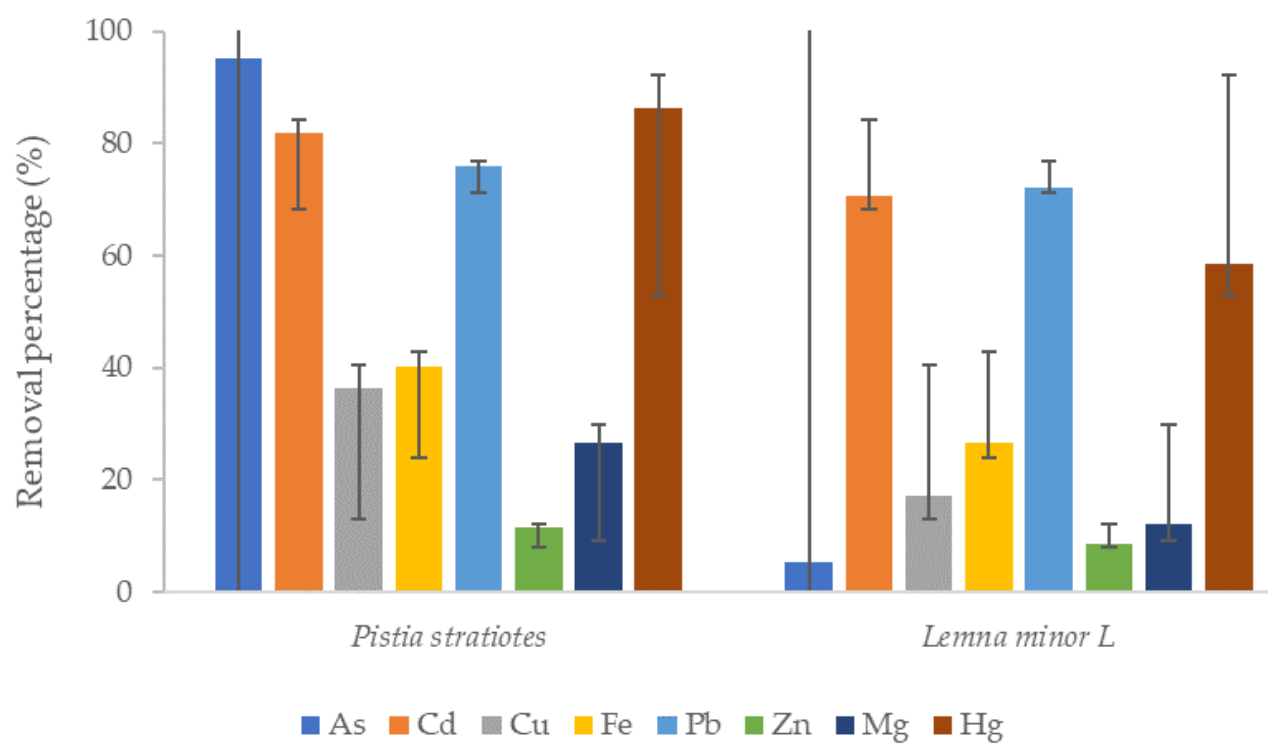

Figure 7. Reduction percentage of heavy metals by Pistia stratiotes and Lemna minor L.

As shown in Figure 7, it was demonstrated that Pistia stratiotes was able to reduce the concentration of $\mathrm{As}, \mathrm{Cd}, \mathrm{Cu}, \mathrm{Fe}, \mathrm{Pb}, \mathrm{Zn}, \mathrm{Mg}$ and $\mathrm{Hg}$ up to $96.62 \%, 95.65 \%, 60.38 \%$, $61.67 \%, 99.24 \%, 32.97 \%, 53.23 \%$ and $96.59 \%$, respectively. As reported by Tabinda et al. (2020), Pistia stratiotes was able to accumulate about $91.5 \%$ of $\mathrm{Cu}$ and $77.3 \%$ of $\mathrm{Cr}$ after 30 days of treatment. In a study performed by Rodrigues et al. (2020), the removal percentage of $\mathrm{Zn}$ by Pistia stratiotes reached a maximum value of $72 \%$ after 7 days of culture in $1.8 \mathrm{mg} / \mathrm{L}$ of $\mathrm{Zn}$. Those studies found that higher accumulation of metals was observed in the roots of the plant. This is because Pistia stratiotes has a fibrous root system which help the plant to tolerate high concentrations of heavy metals. According to Akhtar et al. (2017), Pistia stratiotes can removed heavy metals without caused any damage to the metals. Pistia stratiotes has a rapid growth rate which make it able to accumulate high amount of nutrients to grow (Nizam et al., 2020). As stated by Hanafiah et al. (2018b), the ability of Pistia stratiotes in heavy metals and nutrients accumulation making this plant suitable to be used in phytoremediation treatment of contaminated wastewater.

While Lemna minor L. removed up to approximately $10.97 \%, 83.33 \%, 35.75 \%$, $39.97 \%, 100 \%, 15.32 \%, 23.81 \%$ and $90.91 \%$ of $\mathrm{As}, \mathrm{Cd}, \mathrm{Cu}, \mathrm{Fe}, \mathrm{Pb}, \mathrm{Zn}, \mathrm{Mg}$ and $\mathrm{Hg}$, respectively (Figure 7). Bokhari et al. (2016) reported that Lemna minor was more effective in accumulating $\mathrm{Pb}$ other than other metals, which was similar with the results 
obtained from the current study. However, Daud et al. (2018) found a maximum value of reduction for $\mathrm{Cu}$ which was $91 \%$. Lemna minor is widely distributed throughout the world and can usually be found in ponds, swamps and ditches which were rich in nutrient content (Hazmi and Hanafiah, 2018; Hanafiah et al., 2019). Lemna minor L. can adapt extreme climatic and weather conditions such as drought, flood, frost, heat wave and inundation due to its physical characteristics (Ekperusi et al., 2019). Lemna minor L. can survive up to one months in drought. The plant also able to tolerate flood and areas where there is a high amount of water, for instance, it can be submerged for more than 120 days (Mohedano et al., 2012), making it perfect for wetlands because it can consume high amount of water. According to Radic et al. (2010), Lemna minor has been recommended for wastewater treatment because this plant is more tolerant to cold, easily harvested and also has a rapid growth rate, thus, it can be a better alternative for monitoring heavy metals content. Table 4 shows the findings from several previous studies on the phytoremediation of heavy metals by Pistia stratiotes and Lemna minor L.

Table 4. Phytoremediation of heavy metals by Pistia stratiotes and Lemna minor L.

\begin{tabular}{l|c|c|c|c}
\hline Type of plant & Heavy metals & Removal rate (\%) & Duration & Authors \\
\hline & $\mathrm{Cu}, \mathrm{Cr}$ & $91.5,77.3$ & 30 days & Tabinda et al. (2020) \\
& $\mathrm{Zn}$ & 72 & 7 days & Rodrigues et al. (2020) \\
Pistia stratiotes & $\mathrm{Pb}, \mathrm{Cu}$ & $70.7,66.5$ & 30 days & Aurangzeb et al. (2014) \\
& $\mathrm{Ca}, \mathrm{Mg}, \mathrm{Na}, \mathrm{K}$ & $57,55,43,54$ & 60 days & Kumar et al. (2017) \\
& $\mathrm{Cd}$ & 27.1 & 28 days & Kodituwakku and Yatawara (2020) \\
\hline & $\mathrm{Pb}, \mathrm{Cd}, \mathrm{Cu}, \mathrm{Ni}$ & $97,94,94,99$ & 31 days & Bokhari et al. (2016) \\
& $\mathrm{Cu}$ & 91 & 14 days & Daud et al. (2018) \\
Lemna minor $L$. & $\mathrm{Cu}, \mathrm{Ni}, \mathrm{Pb}$ & $58,68,62$ & 10 days & Yilmaz and Akbulut (2011) \\
& $\mathrm{K}$ & 91.32 & 20 days & Mishra et al. (2012) \\
& $\mathrm{Ca}, \mathrm{Mg}$ & $45.7,32.3$ & 30 days & Farid et al. (2013) \\
\hline
\end{tabular}

It can be deduced that Pistia stratiotes reduced higher percentage of most heavy metals concentration as compared to Lemna minor L. Nonetheless, both Pistia stratiotes and Lemna minor L. plant have a very strong phytoremediation ability in heavy metals removal during the incubation days inside water pot in the laboratory. The absence of sunlight, spaces of growth, less oxygen, reduction of nutrition and other environmental factors after 14 days of growth have affected the plant capability to remove heavy metals from river water samples in the laboratory (Rezania et al., 2015; Suelee et al., 2017). Both Pistia stratiotes and Lemna minor L treatments achieved some reduction in heavy metals concentration, but samples were too variable within each site to be considered as significant at the real replication on site. Heavy metals uptake by the same plants showed well-marked cultivar differences in successive growing seasons in another field experiment in the Czech Republic. Pistia stratiotes and Lemna minor L. were best known as rhizofiltrator and phytoextractor due to their ability to accumulate more heavy metals in the roots when being contacted with water for 7 to 14 days (Barchanska et al., 2019; Ekperusi et al., 2019). 


\section{Conclusions}

Monitoring programs with frequent water samplings and determination of physiochemical parameters may representatively provide the status of the surface water quality. Overall, the WQI of the river water samples for rainy period and dry period was classified in classes II and III, respectively. Both plants, Pistia stratiotes and Lemna minor L. were a good phytoremediation agent especially in removal of heavy metals between 7 to 14 days of incubation. ST1, ST2, and ST3 of Klang River were high polluted by total coliform bacteria byF 17500, 11300 and $10700 \mathrm{CFU} / 100 \mathrm{~mL}$, respectively. The authorities must be aware of the implications and limitations of benchmarking using the INWQS and WQI, so that river water quality preservation efforts can be executed seamlessly. More importantly is the effective utilization of these methods by the responsible agencies and parties involved in watershed management.

Based on the findings of the present study, it is recommended that phytoremediation plants like Pistia stratiotes and Lemna minor L. be planted on both sides of the river by placing simple barrier to locate the plant and keeping it in place to optimize heavy metals uptake. Future studies can be conducted to explore more on the pollutants uptake mechanism in terms of toxicity, tolerance towards heavy metals and accumulation of heavy metals in the plants. Besides, the study of phytoremediation by these plants should be carried-out in a longer time length as the time required for plant cultivation as well as plant acclimatization would take a very long time, especially the plant cultivation which would take up to at least few months. It also suggested to increase water tests for total and fecal coliform during the two sessions in different stations in Klang River and other rivers to reduce the pollutions and infection by this pathogenic bacterium. Cooperation from various authorities in Klang River basin management, flood mitigation, and environmental improvement through river basin management training, workshops, forums and regional technical assistance should be improved.

Acknowledgements. Marlia Mohd Hanafiah was financed by the UKM research grants (GUP-2020-034 and DIP-2019-001).

\section{REFERENCES}

[1] Akhtar, A. B. T., Yasar, A., Ali, R., Irfan, R. (2017): Phytoremediation using aquatic macrophytes. - In; Ansari, A., Gill, S., Gill, R. R., Lanza, G., Newman, L. (eds.) Phytoremediation. Springer, Cham, Switzerland, pp. 259-276.

[2] Al-Raad, A. A., Hanafiah, M. M., Naje, A. S., Ajeel, M. A. (2020): Optimized parameters of the electrocoagulation process using a novel reactor with rotating anode for saline water treatment. - Environmental Pollution 265: 115049.

[3] APHA. (1995): Standards methods for the examination of water and wastewater. $-\left(19^{\text {th }}\right.$ ed.) American Public Health Association Inc. Washington, DC, USA.

[4] APHA. (1998): Standard methods for the examination of water and wastewater. American Public Health Association Inc. Washington, DC, USA.

[5] Ashraf, M. A., Hanafiah, M. M. (2017): Recent advances in assessment on clear water, soil and air. - Environmental Science and Pollution Research 24: 22753-22754.

[6] Ashraf, M. A., Hanafiah, M. M. (2019): Sustaining life on earth system through clean air, pure water, and fertile soil. - Environmental Science and Pollution Research 26: 1367913680. 
[7] Asman, N. S., Halim, A. A., Hanafiah, M. M., Ariffin, F. D. (2017): Determination of Rainwater Quality from Rainwater Harvesting System at Ungku Omar College, UKM Bangi. - Sains Malaysiana 46: 1211-1219.

[8] Aurangzeb, N., Nisa, S., Bibi, Y., Javed, F., Hussain, F. (2014): Phytoremediation potential of aquatic herbs from steel foundry effluent. - Brazilian Journal of Chemical Engineering 31: 881-886.

[9] Awotedu, O. L., Ogunbamowo, P. O. (2019): Comparative heavy metal uptake and phytoremediation potential of three jatropha species. - Environmental Ecosystem and Science 3: 26-30.

[10] Aziz, N. I. H. A., Hanafiah, M. M. (2020): Application of life cycle assessment for desalination: progress, challenges and future directions. - Environmental Pollution 268: 115948.

[11] Aziz, N. I. H. A., Hanafiah, M. M., Halim, N. H., Fidri, P. A. S. (2020): Phytoremediation of TSS, $\mathrm{NH}_{3}-\mathrm{N}$ and COD from Sewage Wastewater by Lemna minor L., Salvinia minima, Ipomea aquatica and Centella asiatica. - Applied Science 10: 5397.

[12] Balleste, E., Belanche-Munoz, L. A., Farnleitner, A. H., Linke, R., Sommer, R., Santos, R., Monteiro, S., Maunula, L., Oristo, S., Tiehm, A., Stange, C., Blanch, A. R. (2020): Improving the identification of the source of faecal pollution in water using a modelling approach: from multi-source to aged and diluted samples. - Water Research 171: 115392.

[13] Banch, T. J., Hanafiah, M. M., Alkarkhi, A. F. M., Salem, A. M. (2019a): Factoral design and optimization of landfill leachate treatment using tannin-based natural coagulant. Polymers 11(8): 1349.

[14] Banch, T. J., Hanafiah, M. M., Alkarkhi, A. F. M., Salem, A. M. (2019b): Statistical evaluation of landfill leachate system and its impact on groundwater and surface water in Malaysia. - Sains Malaysiana 48: 2391-2403.

[15] Banch, T. J. H., Hanafiah, M. M., Alkarkhi, A. F. M., Amr, S. S. A., Nizam, N. U. M. (2020): Evaluation of Different Treatment Processes for Landfill Leachate Using Low-Cost Agro-Industrial Materials. - Processes 8: 111.

[16] Barchanska, H., Plonka, J., Jaros, A., Ostrowska, A. (2019): Potential application of Pistia stratiotes for the phytoremediation of mesotrione and its degradation products from water. - International Journal of Phytoremediation 21: 1090-1097.

[17] Bokhari, S. H., Ahmad, I., Hassan, M. M. U., Mohammad, A. (2016): Phytoremediation potential of Lemna minor L. for heavy metals. - International Journal of Phytoremediation 18: 25-32.

[18] Clark, R. B. (1982): Nutrient solution growth of sorghum and corn in mineral nutrition studies. - Journal of Plant Nutrition 5: 1039-1057.

[19] Daud, M. K., Ali, S., Abbas, Z., Zaheer, I. E., Riaz, M. A., Malik, A., Hussain, A., Rizwan, M., Rehman, M. Z. U., Zhu, S. J. (2018): Potential of duckweed (Lemna minor) for the phytoremediation of landfill leachate. - Journal of Chemistry 2018: 3951540.

[20] DOE. (2018): Malaysia Environmental Quality Report. - Department of Environment, Ministry of Natural Resources and Environment Malaysia (NRE).

[21] Ekperusi, A. O., Sikoki, F. D., Nwachukwu, E. O. (2019): Application of common duckweed (Lemna minor) in phytoremediation of chemicals in the environment: state and future perspective. - Chemosphere 223: 285-309.

[22] Farid, M., Irshad, M., Fawad, M., Ali, Z., Eneji, A. E., Aurangzeb, N., Mohammad, A., Ali, B. (2013): Effect of cyclic phytoremediation with different wetland plants on municipal wastewater. - International Journal of Phytoremediation 16: 572-581.

[23] Geiger, A., Cooper, J. (2010): Overview of airborne metals regulations, exposure limits, health effects, and contemporary research. - US Environmental Protection Agency.

[24] Ghazali, N. F. M., Hanafiah, M. M. (2016): Malaysian water footprint accounts: blue and green water footprint of rice cultivation and the impact of water consumption in Malaysia. - AIP Conference Proceedings 1784: 060025. 
[25] Halim, A. A., Hanafiah, M. M., Khairi, A. (2017): Ammonia removal from sewage wastewater using chemically modified sand. - Applied Ecology and Environmental Research 15: 521-528.

[26] Hanafiah, M. M., Mohamad, N. H. S. M., Aziz, N. I. H. A. (2018a): Salvinia molesta dan Pistia stratiotes sebagai agen fitoremediasi dalam rawatan air sisa kumbahan. - Sains Malaysiana 47: 1625-1634.

[27] Hanafiah, M. M., Yussof, M. K. M., Hasan, M., Abdulhasan, M. J., Toriman, M. E. (2018b): Water quality assessment of Tekala River, Selangor, Malaysia. - Applied Ecology and Environmental Research 16(4): 5157-5174.

[28] Hanafiah, M. M., Ghazali, N. F., Harun, S. N., Abdulaali, H., Abdulhasan, M. J., Kamarudin, M. K. A. (2019): Assessing water scarcity in Malaysia: a case study of rice production. - Desalination and Water Treatment 149: 274-287.

[29] Hanafiah, M. M., Zainuddin, M. F., Nizam, N. U. M., Halim, A. A., Rasool, A. (2020): Phytoremediation of aluminum and iron from industrial wastewater using Ipomea aquatica and Centella asiatica. - Applied Science 10: 3064.

[30] Harun, S. N., Hanafiah, M. M. (2018): Estimating the country-level water consumption footprint of selected crop production. - Applied Ecology and Environmental Research 16: 5381-5403.

[31] Harun, S. N., Hanafiah, M. M., Aziz, N. I. H. A. (2020): An LCA-based environmental performance of rice production for developing a sustainable agri-food system in Malaysia. - Environmental Management 67: 146-161.

[32] Hazmi, N. I. A., Hanafiah, M. M. (2018): Phytoremediation of livestock wastewater using Azolla filiculoides and Lemna minor. - Environmental Ecosystem and Science 2: 13-16.

[33] Ismail, Z., Salim, K. (2013): Determination of critical factors in implementing river cleanup projects: A Malaysian case study. - CLEAN - Soil, Air, Water 41: 16-23.

[34] Ismail, H., Hanafiah, M. H. (2019): Discovering opportunities to meet the challenges of an effective waste electrical and electronic equipment recycling system in Malaysia. - Journal of Cleaner Production 238: 117927.

[35] Jayasri, M. A., Suthindhiran, K. (2017): Effect of zinc and lead on the physiological and biochemical properties of aquatic plant Lemna minor: its potential role in phytoremediation. - Applied Water Science 7: 1247-1253.

[36] Jindal, R., Sharma, C. (2011): Studies on water quality of Sutlej River around Ludhiana with reference to physicochemical parameters. - Environmental Monitoring and Assessment 174: 417-425.

[37] Kamarudin, M. K. A., Sulaiman, N. H., Wahab, N. A., Toriman, M. E., Hanafiah, M. M., Umar, R., Hassan, A. R., Rosli, M. H., Samah, M. A. A., Harith, H. (2019): Impact of Malaysia major flood to river geomorphology changes and total suspended solid using GIS technique. - Desalination and Water Treatment 149: 242-257.

[38] Kemker, C. (2014): Turbidity, total suspended solids and water clarity. Fundamentals of Environmental Measurements. - Fondriest Environmental Learning Center, Inc.: 13.

[39] Khataee, A. R., Movafeghi, A., Torbati, S., Lisar, S. Y. S., Zarei, M. (2012): Phytoremediation potential of duckweed (Lemna minor L.) in degradation of C.I. Acid Blue 92: artificial neural network modeling. - Ecotoxicology and Environmental Safety 80: 291298.

[40] Kodituwakku, K. A. R. K., Yatawara, M. (2020): Phytoremediation of industrial sewage sludge with Eichhornia crassipes, Salvinia molesta and Pistia stratiotes in batch fed free water flow constructed wetlands. - Bulletin of Environmental Contamination and Toxicology 104: 627-633.

[41] Kumar, V., Singh, J., Pathak, V. V., Ahmad, S., Kothari, R. (2017): Experimental and kinetics study for phytoremediation of sugar mill effluent using water lettuce (Pistia stratiotes L.) and its end use for biogas production. - Biotechnology 7: 330 . 
[42] Lin, H., Batty, M., Jørgensen, S. E., Fu, B., Konecny, M., Voinov, A., Torrens, P., Lu, G., Zhu, A., Wilson, J. P., Gong, J. (2015): Virtual environments begin to embrace processbased geographic analysis. - Transactions in GIS 19: 493-498.

[43] Manikam, M. K., Halim, A. A., Hanafiah, M. M., Krishnamoorthy, R. R. (2019): Removal of ammonia nitrogen, nitrate, phosphorus and COD from sewage wastewater using palm oil boiler ash composite adsorbent. - Desalination and Water Treatment 149: 23-30.

[44] Mishra, S., Mohanty, M., Pradhan, C., Patra, H. K., Das, R., Sahoo, S. (2012): Physicochemical assessment of paper mill effluent and its heavy metal remediation using aquatic macrophytes-a case study at JK Paper mill, Rayagada, India. - Environmental Monitoring and Assessment 185: 4347-4359.

[45] Mohedano, R. A., Costa, R. H. R., Tavares, F. A., Filho, P. B. (2012): High nutrient removal rate from swine wastes and protein biomass production by full-scale duckweed ponds. - Bioresource Technology 112: 98-104.

[46] Ng, Y. S., Chan, D. J. C. (2016): Wastewater phytoremediation by Salvinia molesta. Journal of Water Processing and Engineering 15: 107-115.

[47] Nizam, N. U. M., Hanafiah, M. M., Noor, I. M., Karim, H. I. A. (2020): Efficiency of five selected aquatic plants in phytoremediation of aquaculture wastewater. - Applied Science 10: 2712.

[48] Radic, S., Stipanicev, D., Cvjetko, P., Mikelic, I. L., Rajcic, M. M., Sirac, S., Kozlina, B. P., Pavlica, M. (2010): Ecotoxicological assessment of industrial effluent using duckweed (Lemna minor L.) as a test organism. - Ecotoxicology 19: 216-222.

[49] Rezania, S., Ponraj, M., Talaiekhozani, A., Mohamad, S. E., Din, M. F. M., Taib, S. M., Sabbagh, F., Sairan, F. M. (2015): Perspectives of phytoremediation using water hyacinth for removal of heavy metals, organic and inorganic pollutants in wastewater. - Journal of Environmental Management 163: 125-133.

[50] Rodrigues, A. C. D., de Castro Rocha, M. V., Lima, E. S. A., de Pinho, C. F., dos Santos, A. M., dos Santos, F. S., do Amaral Sobrinho, N. M. B. (2020): Potential of water lettuce (Pistia stratiotes L.) for phytoremediation: physiological responses and kinetics of zinc uptake. - International Journal of Phytoremediation 22(10): 1019-1027.

[51] Safauldeen, S. H., Hasan, H. A., Abdullah, S. R. S. (2019): Phytoremediation efficiency of water hyacinth for batik textile effluent treatment. - Journal of Ecology Engineering 20: 177-187.

[52] Schwantes, D., Goncalves Jr, A. C., da Paz Schiller, A., Manfrin, J., Campagnolo, M. A., Somavilla, E. (2019): Pistia stratiotes in the phytoremediation and post-treatment of domestic sewage. - International Journal of Phytoremediation 21(7): 714-723.

[53] Selamat, S. N., Abdullah, S. R. S., Idris, M. (2014): Phytoremediation of lead (Pb) and arsenic (As) by Melastoma malabathriculum L. from contaminated soil in separated exposure. - International Journal of Phytoremediation 16: 694-703.

[54] Suelee, A. L., Hasan, S. N. M. S., Kusin, F. M., Yusuff, F. M., Ibrahim, Z. Z. (2017): Phytoremediation potential of vetiver grass (Vetiveria zizanioides) for treatment of metalcontaminated water. - Water, Air and Soil Pollution 228: 158.

[55] Sun, P., Zhang, Q., Lu, X., Bai, Y. (2012): Changing properties of low flow of the Tarim River basin: possible causes and implications. - Quaternary International 282: 78-86.

[56] Suratman, S., Sailan, M., Hee, Y., Bedurus, E., Latif, M. T. (2015): A preliminary study of water quality index in Terengganu river basin, Malaysia. - Sains Malaysiana 44: 67-73.

[57] Tabinda, A. B., Irfan, R., Yasar, A., Iqbal, A., Mahmood, A. (2020): Phytoremediation potential of Pistia stratiotes and Eichhornia crassipes to remove chromium and copper.Environmental Technology 41: 1514-1519.

[58] Tunca, E. U., Terzioglu, K., Ture, H. (2017): The effects of alginate microspheres on phytoremediation and growth of Lemna minor in the presence of Cd. - Chemistry and Ecology 33: 652-668. 
[59] Ugya, A. Y. (2015): The efficiency of Lemna minor L. in the phytoremediation of Romi stream: a case study of Kaduna refinery and petrochemical company polluted stream. Journal of Applied Biology and Biotechnology 3: 11-14.

[60] Wahab, N. A., Kamarudin, M. K. A., Toriman, M. E., Juahir, H., Saad, M. H. M., Ata, F. M., Ghazali, A., Hassan, A. R., Abdullah, H., Maulud, K. N., Hanafiah, M. M., Harith, H. (2019): Sedimentation and water quality deterioration problems at Terengganu River Basin, Terengganu, Malaysia. - Desalination and Water Treatment 149: 228-241.

[61] Yilmaz, D. D., Akbulut, H. (2011): Effect of circulation on wastewater treatment by Lemna gibba and Lemna minor (floating aquatic macrophytes). - International Journal of Phytoremediation 13: 970-984. 